\title{
A Scientometric Analysis of Remanufacturing by Mapping Scientific, Organizational and National Concentration Zones
}

\author{
Sercan Ozcan ${ }^{1,2}$, Adnan Corum ${ }^{3}$ \\ 1 Portsmouth Business School, University of Portsmouth, Portsmouth, United Kingdom \\ 2 Department of Engineering Management, Bahcesehir University, Istanbul, Turkey \\ 3 Department of Industrial Engineering, Bahcesehir University, Istanbul, Turkey \\ E-mail: sercan.ozcan@port.ac.uk; adnan.corum@eng.bau.edu.tr
}

\begin{abstract}
The considerations of global sustainability have dramatically increased the importance of the remanufacturing process. Many scholars have started focusing on this vital area from both a management and an engineering point of view. Previous studies have aimed to categorize this area using traditional review approaches, using a smaller body of literature and mostly focusing on the managerial aspects of remanufacturing. Our study is the only study for which techmining and scientometric methods are used to examine remanufacturing research, for the purpose of identifying top actors and key trends with regards to business and technological approaches. We combine both management and engineering related studies in this scientometric study. The results shed light on the principal actors, nations, organizations and scientific domains in this field. Remanufacturing research is categorized using the co-occurrence based clustering method. This study identifies four broad research clusters: (1) Production planning and control of remanufacturing, (2) Material and remanufacturing engineering, (3) Supply chain management of remanufacturing process and, (4) Remanufacturing applications and new trends. This study offers benefits to numerous parties: policymakers in the remanufacturing field, academics who wish to see the research domains and those practitioners interested in the key management, processes, and technologies of remanufacturing activities.
\end{abstract}

Keywords: Remanufacturing, Tech-mining, Data Visualization, Scientometrics, Technology Analysis

\section{Introduction}

Organizations are actively looking for alternative ways to value their products after their economic life, not only to reap the economic benefits but also due to new regulations and a growing environmental awareness in the business world. Today, there are regulations and public concerns about the end-of-life of products, and sustainability is a pressing issue for the wider community. Customers and authorities are encouraging firms to recover their used products and establish an environmentally friendly system throughout all their processes. The OECD began to work on a programme called Extended Producer Responsibility (EPR) in 1994. This is an environmental policy that steers producers to be responsible for their end-of-life products. Most OECD countries are now implementing EPR policies in key sectors such as packaging, electronics, batteries and vehicles (OECD, 2001; Smith, 2005; OECD, 2014; Corum, 2016). 
Product or component recovery options are defined in the literature in the following categories: (Thieery et al., 1995; Oh \& Hwang, 2006; King et al., 2006): (1) Recycling: Discarded materials are collected, sorted, processed and used in the production of new products (King et al., 2006); (2) Direct Reuse: Products are reused directly or after minor maintenance and cleaning; (3) Repair: Damaged parts are replaced or upgraded to working order (Tang \& Naim, 2004); (4) Refurbishing: Used products are disassembled into modules, following which critical modules are inspected and fixed or replaced (Thierry et al., 1995); and (5) Remanufacturing: Used products are completely disassembled and all modules and parts are extensively inspected, and worn-out parts are removed and replaced to bring the quality standard of the final product to like-new condition (Thierry et al., 1995). In remanufacturing, the main purpose is to return the product to like-new condition (Oh \& Hwang, 2006) and this is the only product recovery method that returns the used products to the original equipment manufacturer (OEM) performance specification (King et al., 2006).

When the characteristics of different recovery options are compared, it is evident that remanufacturing is distinctly different from other operations, since the products are disassembled completely, and all parts are returned to like-new condition. The different characteristics and main differences between the product recovery options are listed in Table 1; note that remanufacturing is the only method for which part level disassembly results in a completely new product.

Table 1 Comparison of product recovery options (Thieery et al., 1995)

\begin{tabular}{|l|l|l|l|}
\hline Recycling & Level of Disassembly & $\begin{array}{l}\text { Quality } \\
\text { Requirements }\end{array}$ & Resulting Product \\
\hline To material level & $\begin{array}{l}\text { High for production of } \\
\text { original parts; less for } \\
\text { other parts }\end{array}$ & $\begin{array}{l}\text { Materials reused to } \\
\text { produce new parts }\end{array}$ \\
\hline Repair & To product level & $\begin{array}{l}\text { Restore product to } \\
\text { working order }\end{array}$ & $\begin{array}{l}\text { Some parts fixed or } \\
\text { replaced by spares }\end{array}$ \\
\hline To module level & $\begin{array}{l}\text { Inspect all critical } \\
\text { modules and upgrade } \\
\text { to specified quality } \\
\text { level }\end{array}$ & $\begin{array}{l}\text { Some modules } \\
\text { repaired/replaced; potential } \\
\text { upgrade }\end{array}$ \\
\hline Remanufacturing & To part level & $\begin{array}{l}\text { Inspect all modules } \\
\text { and parts and upgrade } \\
\text { to a new }\end{array}$ & $\begin{array}{l}\text { Used and new } \\
\text { modules/parts combined } \\
\text { into a new product; } \\
\text { potential upgrade }\end{array}$ \\
\hline
\end{tabular}

Considering the different characteristics and functions of the remanufacturing process, it is clear that this field has similar research and application concerns compared to other recovery options. However, there is still little clarity in the remanufacturing field with regards to its sub-areas and cluster of studies, these clusters' intersections with each other, and the emerging areas and gaps. The remanufacturing field could also benefit from bibliometric results showing key national and organizational involvement and these actors' key focus areas and capabilities. Moreover, there is also little knowledge of the current scientific development by its research areas and the 
application of the remanufacturing field to different sectors and products. Therefore, this field could be considerably enhanced by a close examination of these research issues.

Some of the reviewed studies in the remanufacturing area have focused on different business operations and also attempted to categorize the remanufacturing field (Bras and McIntosh, 1999; Guide et al., 1999; Guide, 2000; Hatcher et al., 2011; Junior and Filha, 2012; Chen et al., 2014; Pourghadim et al., 2014; Kumar and Ramachandran, 2016; Priyono et al., 2016). All these studies have used narrative or systematic literature review as a qualitative approach. However, remanufacturing research can also be analysed by means of a quantitative approach following a bibliometric and/or scientometrics study, by adopting a tech-mining method as used by Porter and Cunningham (2004), and Ozcan and Islam (2017). This quantitative approach can assist in identifying the key research focus areas studied by other scholars in this field based on pure statistical metrics and the association of terms. Considering the methodological gap in remanufacturing studies, this is the only scientometrics study that aims to identify scientific, organizational and national concentration zones. Our study is divided into three main sections: first, the relevant literature is examined using a narrative approach; second, the applied tech-mining method is described and, finally, the bibliometric and the scientometric results are analysed to enable the categorization of remanufacturing research.

The implications of scientometric results can help relevant managers with regards to R\&D and operations related decisions on potential investment areas, new research fields, and external collaborations. Using the existing stream of remanufacturing research, engineers and researchers in this field can identify new areas to focus on, understand key research domains and select future research directions.

Scientometric results can also provide valuable input data for policy-makers to establish research objectives and target funding mechanisms. For policy-makers, continuously tracking research trajectories, emerging fields or declining areas is vital in order to establish special funding efforts and facilitating conditions. The specific indicators and results for remanufacturing highlighted in our research provides the required information needed to evaluate research performance at individual, organizational and national levels. Finally, as the remanufacturing area exhibits interdisciplinary characteristics, relevant stakeholders are able to observe the convergence between different disciplines and areas in this field.

\section{Background to the Remanufacturing Field and Relevant Literature}

After the late 1970s, interest in remanufacturing as an academic research topic began to grow, following Prof. Robert Lund's original studies of the remanufacturing industry (Hatcher et al., 2011). Many types of research use Lund's (1983) remanufacturing definition:

Remanufacturing is an industrial process in which worn-out products are restored to like-new condition. Through a series of industrial processes in a factory environment, a discarded product is completely disassembled. Useable parts are cleaned, refurbished, and put into inventory. Then the new product is reassembled from the old and, where necessary, new parts to produce a fully equivalent and sometimes superior in performance and expected lifetime to the original new product. 
The concept of product recovery is not new, and remanufacturing became more common following the Second World War (Östlin et al., 2008). While the symbol of 20th-century industry was the assembly line, the symbol of 21th-century industry may well be the disassembly line (Ebersole, 1997). Many organizations now design products for both assembly and disassembly in a closed-loop fashion.

Remanufacturing is considered in the context of circular economy initiatives. The circular economy has been popularized, especially in the industrial economies, by the Ellen MacArthur Foundation, and it supports complicated operations such as remanufacturing for an industrial economy. It is an economic strategy that suggests innovative ways to transform the current predominantly linear system of consumption into a circular one, while achieving economic sustainability with much needed material savings (Sing and Ordonez, 2016). A primary tenet of the circular economy is the idea of a restorative, self-generating ecosystem where system waste is recaptured for use as future input (Hazen et al., 2017).

A circular economy offers benefits that are operational as well as strategic, on both a micro and macroeconomic level. This is a trillion-dollar opportunity, with huge potential for innovation, job creation and economic growth (Ellen MacArthur Foundation, 2014). The circular economy concept provides a viable path towards sustainability by reversing the current practices of rapid resource depletion and waste generation (Hazen et al., 2017).

The remanufacturing process is popularly used for many products and parts including photocopiers, computers, telecommunication equipment, automotive parts, office furniture and tires. Remanufacturing costs less than producing a new product, as many parts and components can be reused (Ferguson, 2009). Lund and Hauser (2010) listed 113 product areas where remanufacturing is applied in the US, the major ones including: motor vehicle parts, electrical motors and generators, pumps, transformers, laser toner cartridges, industrial machinery, tires, industrial valves and office furniture.

Xerox Corporation is the pioneer company in remanufacturing, focusing on printing-related products. It has been recovering used products since the 1960s, but developed a more formal remanufacturing system in the late 1980s and early 1990s (Kerr and Ryan, 2001). Today, Xerox has saved millions of dollars by remanufacturing; its remanufacturing facilities in the US, UK, Netherlands, Australia, Mexico, Brazil and Japan have helped Xerox to enhance its environmentally conscious company image.

Ferguson (2009) examined Kodak's, Caterpillar's and IBM's remanufacturing activities. Kodak has created a fully integrated manufacturing and remanufacturing strategy around its reusable camera line. In 2007, IBM collected over one million units of used IT equipment that were converted to billions of dollars in revenues by remanufacturing. Similarly, Hewlett Packard (HP) works with third-party remanufacturers and logistics providers to recover inkjet printers (Atasu et al., 2010).

Meanwhile, Matsumoto and Umeda (2011) investigated the Japanese remanufacturing industry. Three major OEMs of photocopy machines in Japan are Fuji Xerox, Ricoh, and Canon, who together own $90 \%$ of Japan's photocopier market. Fuji Xerox started remanufacturing in the 1990s, while Ricoh and Canon began selling remanufactured machines in the 2000s. In Fuji 
Xerox, all products may include reused components and there is no distinction between new and remanufactured products. However, in Xerox US and Europe, remanufactured products are distinguished from new products as in Ricoh and Canon.

Apart from electronics, auto parts are the most remanufactured materials worldwide, accounting for up to two-thirds of the global remanufacturing businesses and including engines, turbochargers, alternators, starters, compressors, transmissions and steering units (Matsumoto $\&$ Umeda, 2011). Alternators and starters represent $80 \%$ of remanufactured auto parts. Valeo and Bosch are two important alternator producers in Europe, who began remanufacturing activities in the early 1990s (Bernard, 2011). Renault Trucks is also benefiting from remanufacturing and has adopted circular economy principles across their business. Renault's remanufacturing plant in Choisy-le-Roi, near Paris, France, employs 325 people and remanufactures different mechanical subassemblies, from water pumps to engines, to be sold at 50 to $70 \%$ of their original price, with a one-year warranty. The remanufacturing operation generates revenues of $\$ 270$ million annually (Ellen MacArthur Foundation, 2014). Remanufactured parts in Renault trucks accounted for $16 \%$ of parts revenues in 2001, and are $30 \%-50 \%$ cheaper than the brand-new ones (Bourgeois and Leleux, 2004).

In addition to application-oriented remanufacturing studies, numerous studies have focused on the ability of the remanufacturing process to increase efficiency and be integrated with existing production lines. Hybrid manufacturing and the remanufacturing system is a recoverable manufacturing system that enables direct manufacturing or remanufacturing depending on the system requirements. Inventory management of these hybrid systems has attracted the most academic attention. Laan and Salomon (1997) considered a stochastic inventory system with production, remanufacturing and disposal. They defined push and pull disposal strategies with a procedure that calculates the total expected cost, and compared the two strategies. Meanwhile, Laan et al. (1999) evaluated a hybrid manufacturing and remanufacturing system for the single component product, comparing the traditional system (without remanufacturing) to push and to pull controlled systems (with remanufacturing) by using the defined cost functions. Both studies concluded that the pull strategy outperforms the push strategy when the cost of recoverable inventory is sufficiently lower than the cost of serviceable inventory. Similarly, Behret and Korugan (2009) modeled and analysed a hybrid manufacturing and remanufacturing system with different quality levels of remanufactured products, return rates and return times of returned products. Their analysis demonstrated that under the different cost scenarios, the quality-based classification of returned products offers significant cost savings.

Some scholars have studied remanufacturing related operations to identify the most optimum conditions. For example, Guide et al. (1997) investigated the effects of product structure on the performance of scheduling operations in a recoverable manufacturing environment. They quantitatively differentiated between three different product structure types and investigated the effects of these product structures on the performance of various scheduling policies, disassembly release mechanisms and priority dispatching rules. Meanwhile, Kenne et al. (2012) studied an integrated hybrid manufacturing and remanufacturing system subject to uncertainties, developing a generic stochastic optimization model with two decision variables (the production rates of manufacturing and remanufacturing machines) and two state variables (the stock levels of manufactured and remanufactured products). In addition, Kiesmüller and 
Laan (2001) developed and investigated an inventory model for a single, reusable product, using a Markov-chain approach to determine the optimal order-up-to policy with respect to the total average cost.

Much research has been conducted in this field to resolve supply chain management related issues. For example, Östlin et al. (2008) studied the supplier relationship management of cores (used products), exploring how customer/supplier relationships perspective can support product take-back for remanufacturing, with a focus on the supply of cores. Meanwhile, Pellerin et al. (2009) addressed the specific case of a remanufacturing organization performing complex remanufacturing programs, presenting an analytical framework for controlling the execution rate of repair and remanufacturing activities. They considered a remanufacturing system repairing a single-product type with stochastic demand, where the operating firm controls both serviceable and non-serviceable stocks.

As part of supply chain related studies, a key area in the literature is bullwhip and order variance effects. The bullwhip effect refers to the phenomenon whereby orders to the supplier tend to have a larger variance than customer orders (Lee et al., 1997). Zhou and Disney (2006) concluded that inventory variance and the bullwhip effect is always less in supply chains with returns; larger product return rate leads to less bullwhip and less inventory variance. Meanwhile, Zanoni et al. (2006) introduced a shifted pull inventory control policy by changing the definition of inventory position of the serviceable stock, which is compared with the pull, dual and separate pull control policies studied previously in the literature. They evaluated different control policies based on cost and the bullwhip effect. Elsewhere, Corum et al. (2014) compared traditional (without remanufacturing) and push and pull controlled manufacturing and remanufacturing hybrid systems under different demand and return rates, manufacturing and remanufacturing lead times, setup and holding cost rates. Production order variances were used to measure the bullwhip effect, and total recoverable and serviceable inventory costs were considered as the main performance indicators. Finally, Pati et al. (2010) developed an analytical expression for measuring the bullwhip effect in a six-echelon closed loop supply chain, for the recycling of products such as paper and plastic.

Apart from supply chain management studies in this area, pricing strategies in remanufacturing have been found to be essential for existing product sales and business operations. Charging the correct price to the remanufactured product is critical in order to avoid cannibalizing the sales of the new product. Guide et al. (2003) developed a simple framework for determining the optimal prices and corresponding profitability, where the profitability of remanufacturing depends on the quantity and quality of product returns and the demand for remanufactured products. They illustrated their framework using an application from the cellular telephone industry. Meanwhile, Subramoniam et al. (2013) developed a remanufacturing decision-making framework (RDMF) to assist original equipment suppliers in their strategic decision-making processes and validated their framework using case studies from the automotive industry. Mitra (2007) developed a pricing model to maximize the expected revenue from the recovered products, studying the problem with different quality levels of the recovered products and presenting numerical examples. Finally, Wu (2012) discussed price competition between an $\mathrm{OEM}$ and a remanufacturer and provided a set of conditions for higher profits. 
For pricing decisions in remanufacturing, the valuation of recoverable and remanufactured products is also critical when making product recovery decisions. Teunter et al. (2000) and Teunter (2001) proposed and compared different methods for calculating the holding cost of returned, remanufactured and manufactured items in production systems, concluding that the value of a new or remanufactured assembly is the same and equal to the cost of a new assembly, where the value of a recoverable assembly is its net profit following remanufacture.

Another group of studies in remanufacturing is related to the overall feasibility of this process. For example, Bulmus et al. (2013) considered the effect of remanufacturing on capacity and production decisions, stating that remanufacturing is rarely profitable if it requires greater initial investment than manufacturing. Moreover, El Saadany et al. (2013) developed a mathematical approach to estimate the number of recovery times, noting that an indefinite number of times to recover is costly and that there is an optimal number that balances investment and remanufacturing costs. Meanwhile, Bayindir et al. (2003) investigated the possible benefits of remanufacturing in inventory-related costs, considering a hybrid manufacturing and remanufacturing system under a wide range of scenarios with different system parameter settings.

As numerous previous studies have demonstrated, as the attention paid to this field by industrial and academic actors increased, so the number of publications increased, and the remanufacturing research evolved with regards to many different business and engineering aspects.

Concerning the recovery process, Johnson and Wang (1995) defined it as a combination of remanufacture, reuse and recycle, while Thierry et al. (1995) divided recovery into repair, refurbish, remanufacture, cannibalize and recycle. Fleischmann et al. (1997), meanwhile, simply categorized recovery into material recovery (recycling) and added value recovery (repair, remanufacturing). Their review of the extant literature is dedicated to the planning and control tasks arising in the context which they addressed from an operational research point of view. They subdivided the field into three main areas: (1) Distribution planning, (2) Inventory control and (3) Production planning. Guide et al. (1999) addressed the production planning and control needs for a remanufacturing firm and discussed the papers in the literature under categories of production planning and control, disassembly operations, production planning and scheduling, inventory control and management. Gungor and Gupta (1999) categorized the recovery process into material recovery (recycling) and product recovery (remanufacturing). They grouped the reviewed work into the following categories: Collection, design for environment, disassembly, disassembly leveling, disassembly process planning, environmentally conscious design, environmentally conscious manufacturing, environmentally conscious production, inventory control, inventory control \& production planning and scheduling, life cycle analysis, materials \& products recovery, production planning and scheduling, recycling, recycling and remanufacturing common, remanufacturing, waste management, and pollution prevention. They also determined and discussed the common issues in recycling and remanufacturing, such as collection issues, disassembly, disassembly leveling (i.e. how far to disassembly), disassembly process planning, inventory control and production planning, and production planning and scheduling. The papers in the literature were grouped under these categories. Meanwhile, Guide (2000) grouped and presented the papers relevant to 
production planning and control in the remanufacturing field as follows: Forecasting, reverse logistics, production planning and control, inventory control and management, and general. Elsewhere, Prahinski and Kocabasoglu (2006) organized the reverse supply chain sequentially into five key steps: product acquisition, reverse logistics, inspection and disposition, reconditioning, and distribution and sales. They structured the discussion of the literature around these five steps and, based on the review of the literature and managerial concerns in the reverse supply chain, created 10 research propositions. Pokharel and Mutha (2009) grouped and listed the papers under the reverse logistics field according to categories of: Inputs, collection, general, inspection and consolidation, integrating manufacturing and remanufacturing, product modularity, disassembly, coordination, supply chain, inventory, repair and after sales services, pricing and competition, and customer relations. Subramoniam et al. (2009) addressed the following strategic factors of remanufacturing and categorized the literature accordingly: Product strategic planning processes, physical distribution structures, plant location and production systems, and cooperation among remanufacturing supply chain stakeholders. For each category, they presented a proposition, including current situation analysis. Meanwhile, Lund and Hauser (2010) categorized remanufacturing organizations into the following: (1) Conventional firms: These purchase cores, remanufacture them and sell them to new owners; (2) Contract firms: These agree with the owner of a product to remanufacture it and return it to the owner; and (3) OEMs: These are manufacturers of a product who also remanufacture their product for resale. The authors described different types of remanufacturing organizations and their types, and some studies explained where remanufacturing is applied, such as the automobile industry and printers. Nonetheless, the focus of remanufacturing in terms of different sectors and types of organizations remains unclear.

Ilgin and Gupta (2010) presented one of the most popular studies in this field: a comprehensive summary of the environmentally conscious manufacturing and product recovery literature. They organized the literature into four main areas: (1) Product design, (2) Reverse and closedloop supply chains, (3) Remanufacturing and (4) Disassembly. Additionally, they organized remanufacturing into six main areas: (1) Forecasting, (2) Production planning, (3) Production scheduling, (4) Capacity planning, (5) Inventory management and (6) Effect of uncertainty (see Figure 1). 


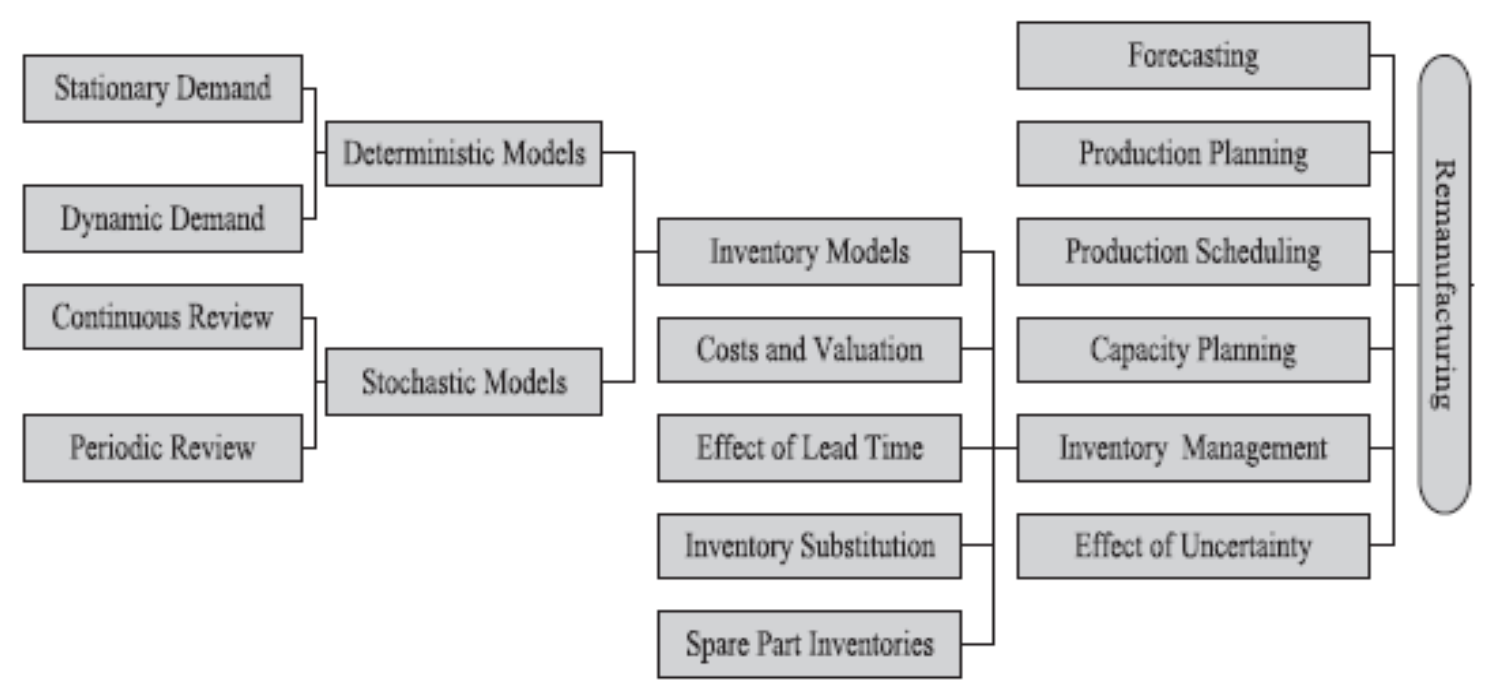

Figure 1: Classification of issues in remanufacturing (Ilgın and Gupta, 2010)

Finally, Lee et al. (2017) reviewed papers under the remanufacturing field according to categories of: Managerial perspective, types of product, and remanufacturing technologies. Each category contains sub categories.

Based on the extensive literature review conducted above, the focus of remanufacturing oriented studies varies regarding supply chain-oriented issues, inventory issues and valuation methods. Although many of the aforementioned researchers have reviewed the existent remanufacturing literature and contributed to the field, the remanufacturing field is still not particularly clear in terms of sub-areas and cluster of studies, these clusters' relationship with each other, emerging areas and gaps that needs to be fulfilled to enhance this field further.

One of the best methods for the classification and clustering of scientific fields is the scientometric approach. As scientometric methods are quantitative in nature, they lead to less biased outputs and provide a better perspective to interpret the scientific developments. Numerous studies have applied similar methods in various emerging fields on publication or patent data (Porter and Cunningham, 2004; Rafols and Meyer, 2007; Shapira et al., 2011; Guan and Zhao, 2013; Leydesdorff, 2018). In particular, Leydesdorff has conducted multiple scientometric studies in which he examines different fields using science subject categories focusing on various topics, such as citation networks, science overlays and the interdisciplinarity of research activities (Leydesdorff and Rafols, 2009; Leydesdorff and Rafols, 2011; Leydesdorff et al., 2013a; Leydesdorff et al., 2013b). These studies are excellent examples of both application and methodological approaches in scientometrics. The number of scientometric studies in this field are related to the emerging or trending areas for understanding key technologies or actors in different domains.

For example, three scientometric studies can be found in the literature even if only solar cell technology specific studies are reviewed. Zhang et al. (2014) worked on dye-sensitized solar cells in their study, using some beneficial methods such as term clumping, tech mining and text clustering. Consequently, their empirical findings contribute to a better understanding of dyesensitized solar cells by using text clustering methods. Newman et al. (2014) also examined dye-sensitized solar cells and used more than 4000 abstracts to complete their analysis, providing solutions for the technological development of dye-sensitized solar cells. Meanwhile. 
Li et al. (2015) also examined solar cells and used bibliometrics and patent analysis to determine the roadmap of this technology. All these authors utilised different scientometric approaches to the same technology, examining different issues.

There are also popular scientometric and network studies where science, technology and innovation (STI) activities are examined. Ogawa and Kajikawa (2014) followed a citation network analysis method with the aim of measuring the relationships of studies within the polymer electrolyte fuel cells area, identifying polymer electrolyte fuel cells research fields specific to some countries. Another popular area in this field is related to the nanotechnology related stream due to its emerging and highly interdisciplinary nature (Leydesdorff and Zhou, 2007; Porter and Youtie, 2009; Arora et al., 2013; Islam and Ozcan, 2013). For example, Guo et al. (2015) studied nano-enhanced drug delivery, applying tech mining techniques to create some empirical identifiers for this field, examining key biomedical areas and presenting estimations on the future of this field.

Having mentioned popular areas and key authors using scientometric and tech mining methods, only two bibliometric studies investigate the remanufacturing area with only statistical measures as an overall focus area or as part of a broader area. Junior and Filho (2012) examined remanufacturing with a production planning control (PCC) lens, presenting the major findings of articles related to production planning and control in the following categories: Forecasting, aggregate planning, master production scheduling (MPS), logistics, ordering systems, capacity planning, scheduling, and inventory control and management,

These authors classified the remanufacturing area mainly following the previous categorization of Guide et al. (1999) and Guide (2000) on PCC activities, the complicating characteristics of PCC, remanufacturing sub-systems and research type. This research has completed the classification process using a traditional literature review method based on 76 articles. The study of Junior and Filho (2012) identified gaps in the PCC research activities for remanufacturing. For example, forecasting, aggregate planning, and the applications of stochastic routings were found to be quite limited. The second bibliometric study in a similar area is the study of Wang et al. (2017), which focused on reverse logistics research using research data from 1992 to 2015 . Although their study focuses on other research topics aside from remanufacturing such as "recycling", it is still relevant, as they investigated many remanufacturing research issues, using a co-citation analysis to investigate co-authorship and network in the reverse logistics area. Research themes in their research area are illustrated based on a close investigation of a group of references. Wang et al. (2017) provided an excellent summary of reverse logistics, including remanufacturing. A close examination of both relevant studies reveals no specific remanufacturing review study using a bibliometric or a scientometric method. Neither study establishes a quantitative grounding for the subareas of remanufacturing research and, accordingly, there is a gap in the literature for classifying and categorizing remanufacturing research using a scientometric approach. The study of Junior and Filho (2012) needs to be extended using a large data set; for example, the research gaps can be confirmed. Similarly, the co-citation and author network related study of Wang et al. (2017) needs to be extended using co-occurrence analysis and a tech-mining approach. 
Considering the research needed in this area, a general research framework is proposed and designed, as illustrated in Figure 2. There may be sub-research areas, as shown by the fields, and these fields may intersect in some areas. Moreover, there may be some intersections where fields merge with each other. Accordingly, the aim of this study is to analyse and explore the remanufacturing literature by using the tech-mining method to identify current scientific development by its research areas and the application of the remanufacturing field to different sectors and products. Most importantly, we aim to categorize and investigate sub-areas of remanufacturing research. We also intend to investigate national, organizational and individual involvements using bibliometric results.

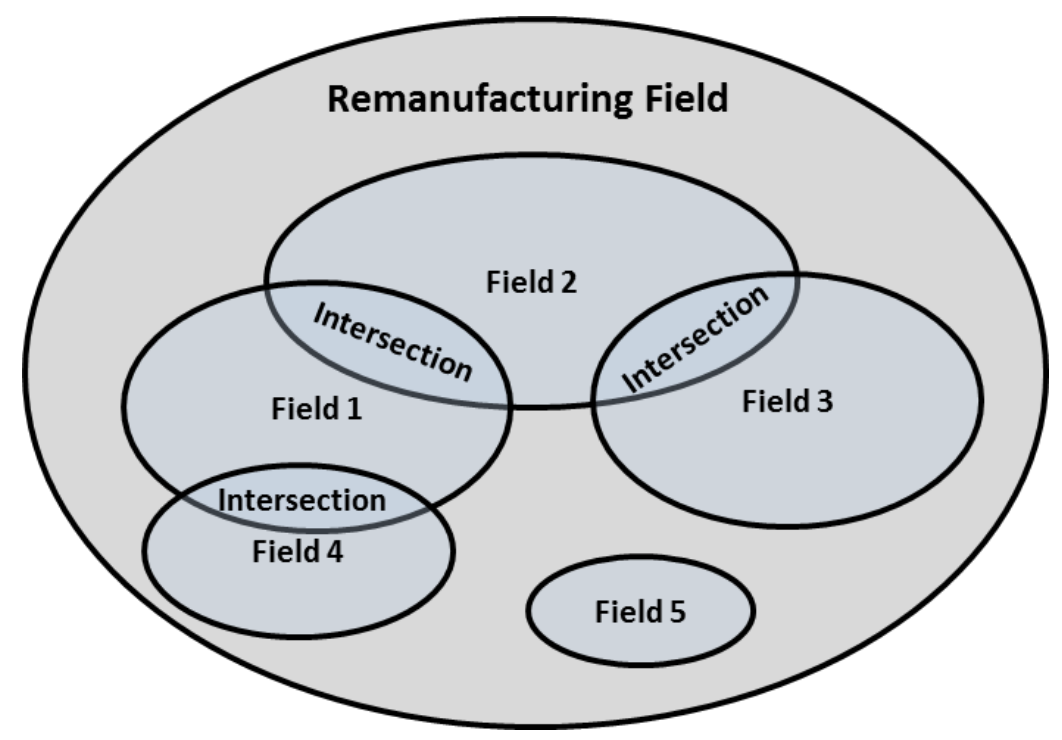

Figure 2: The Proposed Model for the Study

\section{Methodology}

This study uses the tech-mining method to follow a bibliometric and a scientometric study to fulfil the aim of the research by way of analysing journals or other written documents in a selected database. Bibliometric research enables various subjects to be compared between countries, institutions, schools, trends, technologies, etc. The main field of interest of bibliometrics is a citation; the basic idea behind this is the creation of a relationship between the citation document and related person. Scientometrics takes advantages of bibliometrics and interests with the solving of science disciplines. Research on it began in the United States of America in the 1960s and 1970s; similar studies were then conducted in various European countries. Scientometrics is used in several studies that assist with creating and developing an effective science policy. By using similar studies, it is possible to make valid suggestions that are based not only on interpretations and experiences, but statistical terms based on actual scientific measures. Moreover, it is very difficult to analyse fields where there are thousands of documents in databases and it is difficult to estimate the field of studies and scope of the field. 
This study follows a tech-mining method and the bibliometric model used by Porter and Cunningham (2004) and Ozcan and Islam (2017). There are five stages in this study: (1) Data retrieval, (2) Data cleaning and optimization, (3) Data analysis, (4) Data visualization and (5) Data labelling and interpretation. All these stages are significant for the results of the study and increase their validity and reliability. The data for this study were retrieved from the Web of Science, considering the quality and the quantity of the work necessary in order to map the remanufacturing field. To retrieve the required data, a "remanufacturing OR re-manufacturing" search query is used on the title, abstract and key-words to identify required publications. 2839 publications until September 2018 are retrieved, including articles and proceeding papers.

After retrieving data as a full record from the Web of Science Database, all unnecessary papers or words are removed to enhance the results. The retrieved data is cleaned by using VantagePoint software, using their filters to save and transform all into a structured format where analyses can be performed. For example, duplicate papers are removed with the significance of the similarity level between their abstracts and titles. As part of the natural language processing (NLP) phase, the titles and abstracts are tokenized with n-grams model, using VantagePoint's NLP function. As there are many common words used in the literature which are not significant to the study, these unnecessary words are cleaned by the stop words list. To do so, the current stop words list is updated with additional words to eliminate unnecessary words and ensure all remanufacturing related terms are present before the actual analysis begins. Once the words and phrases are listed according to their term frequency value, a minimum 2 term frequency threshold is introduced, before applying the TF-IDF method. The Zipf curve is calculated using MS Excel to select the threshold using TF-IDF results and to choose the subset terms for further analysis. Once the terms are selected, VantagePoint's matrix function is used to create a co-occurrence matrix. Subsequently, the results of the co-occurance matrix are exported to UCINET to calculate centrality measures based on degree centrality (degree, closeness and betweenness are calculated). Once the centrality measures are completed, the data is prepared in .net, .clu and .vec formats in order to feed it into the VOSviewer for visualization outputs.

The retrieved and cleaned data is used by VOSViewer software to visualize by using various techniques such as clustering and network analysis. By way of using the parameters of UCINET, network heat maps are created to increase the clarity of the relationships. VOSViewer is used to perform a bibliometric network analysis such as keyword co-presence analysis by using the distance-based visualization approach. Special labelling techniques are used for finalizing visuals to identify fields and their intersections. Labelling is completed as the final step by using a semi-automated feedback mechanism with allocated keywords for each cluster on the Web of Science database, to retrieve information further and identify the scope of fields.

Data interpretation is completed based on keywords' frequency of appearing together, their volume based on the size of words, based on the centrality of words that show an interlinkage of the field with all other surrounding areas and isolated areas that show areas where there is no such interlinkage. 


\section{Results and Discussions}

This section consists of various descriptive results that present an overview of the remanufacturing research activities, in addition to specific outputs based on the scientometrics section. It is divided into two sub-sections: (1) Descriptive results where generic subject matters, researchers in this field and key organizations are examined, and (2) technologyoriented examinations, where the field is examined based on the tech-mining method, and where key research areas and their intersections are examined.

\subsection{Research Activities in the Remanufacturing Field by Authors, Organizations and Nations}

As mentioned, the results of 2839 publications are represented with the descriptive results to understand the retrieved data in statistical terms prior to the presentation of a scientiometrics map. As demonstrated below in Figure 3, this field appears to have undergone an exponential increase in terms of publication numbers from 2011 to 2017, almost doubling in number, indicating its changing importance in the view of many scholars. The reason for the rapid increase in 2017 may be due to organizations paying more attention to keeping resources in the supply chain. Among the product recovery options, the importance of remanufacturing increased as it carries the used product or component to new product specifications. This has led researchers to publish more studies on remanufacturing.

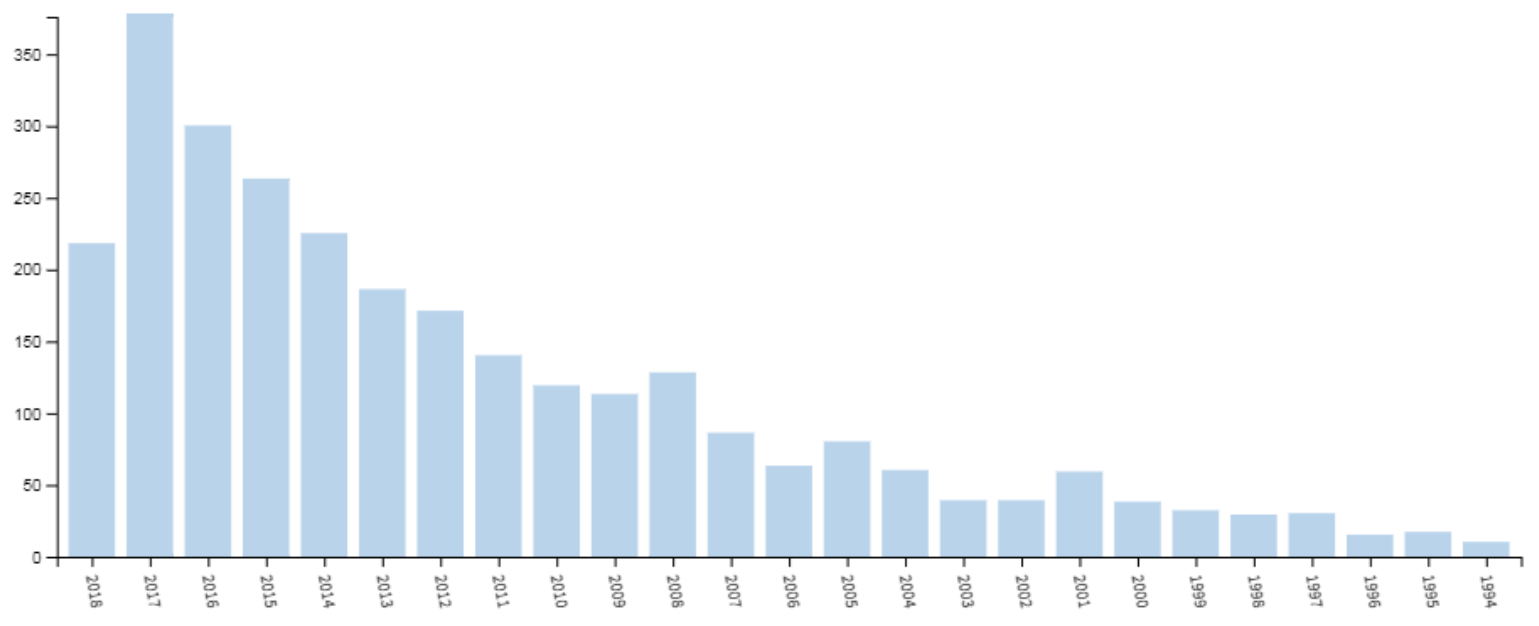

Figure 3: Publications Years in Remanufacturing Field

Table 2 depicts the top authors in this field based on a number of publications recognized by the Web of Science database. They account for over 10\% of all publications in this field. Prof. $\mathrm{Xu} \mathrm{BS}$, who has the maximum number of publications, works on material science and surface engineering applied in remanufacturing, such as experimental observations on surface roughness, coating, etc.; manufacturing characteristics and mechanical properties applied in remanufacturing such as tool wear behaviour, cutting parameters, the failure analysis of components, etc.; and remanufacturing technology, sustainability and the quality of remanufacturing products. Prof. Gupta SM, meanwhile, has publications on disassembly system modelling and design, reverse MRP, disassembly scheduling and sequencing, 
disassembly line balancing, quality management in product recovery and sensor embedded products on the disassembly line. Prof. Gupta has also published two papers reviewing the state of the art of environmentally conscious manufacturing and product recovery in 1999 (1110 citations) and 2010 (639 citations). Meanwhile, Prof. Guide has published on matching demand and supply with remanufacturing strategies, pricing strategies for new and remanufactured products, closed loop supply chain management, cannibalization, optimal order quantities with remanufacturing, managing product returns, and scheduling policies for remanufacturing. $\mathrm{He}$ has also reported on managerial remanufacturing practices via a survey of production planning and control activities at remanufacturing firms in the US, and identifies seven complicated characteristics of remanufacturing in his valuable paper "Production planning and control for remanufacturing: a state-of-the-art survey".

Table 2: Top Authors in Remanufacturing Research

\begin{tabular}{|l|c|c|}
\hline Authors & Record Count & \% of $\mathbf{2 8 3 8}$ \\
\hline XU BS & 64 & $2.26 \%$ \\
\hline GUPTA SM & 50 & $1.76 \%$ \\
\hline GUIDE VDR & 40 & $1.41 \%$ \\
\hline ZHANG HC & 37 & $1.30 \%$ \\
\hline LI YJ & 23 & $0.81 \%$ \\
\hline SUNDIN E & 22 & $0.78 \%$ \\
\hline BEHDAD S & 18 & $0.63 \%$ \\
\hline NEE AYC & 18 & $0.63 \%$ \\
\hline ONG SK & 18 & $0.63 \%$ \\
\hline SRIVASTAVA R & 18 & $0.63 \%$ \\
\hline
\end{tabular}

As illustrated by Table 3, the top 10 nations account for over $90 \%$ of all publications in this field, with China and the US the leading research nations in the remanufacturing area. One of the principal reasons why China is the leading nation in remanufacturing research is their central role in global manufacturing and the types of materials and products they manufacture, many of which lead to sustainability-oriented issues in terms of waste generation. Waste generation is a growing global problem, but China is experiencing the largest and fastest increase in solid waste quantities. Urbanization, population growth and industrialization are three key reasons behind China's considerable increase in total waste generation (Zhang et al., 2010). Many countries, including China, implement legislation to reduce the volume of waste generated and ensure that the producers of such products take responsibility for the treatment and disposal of their waste (Hatcher et al., 2011). Consequently, researchers in China focus more on finding solutions to this problem. Eighty of these publications are funded by the National Natural Science Foundation of China and they consider this field to be a critical one due to the significant increase in total waste generation. 
The USA is the second leading nation in remanufacturing research and believes that it offers tremendous untapped opportunities for American business and increasing material productivity. American OEMs such as General Electric, Boeing, Caterpillar, Deere, Navistar, Xerox and Pitney Bowes have created successful business models in which capital goods remanufacturing is an integral part (Giuntini and Gaudette, 2003). Lund and Hauser (2010) claimed that there are 113 product areas in which remanufacturing occurs in every one of the 50 states of US, in both large and small cities.

Table 3: Top Countries in Remanufacturing Research

\begin{tabular}{|l|c|c|}
\hline \multicolumn{1}{|c|}{ Countries } & Record Count & \% of $\mathbf{2 8 3 8}$ \\
\hline PEOPLES R CHINA & 1,035 & $36.47 \%$ \\
\hline USA & 664 & $23.40 \%$ \\
\hline ENGLAND & 147 & $5.18 \%$ \\
\hline CANADA & 139 & $4.90 \%$ \\
\hline GERMANY & 132 & $4.65 \%$ \\
\hline FRANCE & 119 & $4.19 \%$ \\
\hline INDIA & 108 & $3.81 \%$ \\
\hline JAPAN & 76 & $2.68 \%$ \\
\hline SWEDEN & 71 & $2.50 \%$ \\
\hline TAIWAN & 71 & $2.50 \%$ \\
\hline
\end{tabular}

Table 4 summarizes the top universities in this field by record count. Northeastern University is the leading organization in this field, possessing a Laboratory for Responsible Manufacturing (LRM) in the College of Engineering. One of the areas where the laboratory is conducting basic, as well as applied research, is environmentally conscious manufacturing, which covers remanufacturing. Prof. Gupta SM, one of the top authors in the remanufacturing field, is the director of this laboratory. Linköping University in Sweden is the second leading organization; to meet this increased interest in the process, researchers from Linköping University are heavily involved in the Journal of Remanufacturing, a scientific periodical, whose regional editor is Linköping's own Dr. Erik Sundin. The majority of organizations listed in Table 4 are universities; however, there are some other research-oriented organizations such as the Academy of Armored Forces Engineering China and the United States Department of Defense (US DOD) that are involved in remanufacturing oriented research. 
Table 4: Top Organizations in Remanufacturing Research

\begin{tabular}{|c|c|c|}
\hline Organizations & Record Count & $\%$ of 2838 \\
\hline NORTHEASTERN UNIVERSITY & 58 & $2.04 \%$ \\
\hline ACADEMY OF ARMORED FORCES ENGINEERING CHINA & 56 & $1.97 \%$ \\
\hline DALIAN UNIVERSITY OF TECHNOLOGY & 55 & $1.94 \%$ \\
\hline HUAZHONG UNIVERSITY OF SCIENCE TECHNOLOGY & 48 & $1.69 \%$ \\
\hline CHONGQING UNIVERSITY & 46 & $1.62 \%$ \\
\hline LINKOPING UNIVERSITY & 43 & $1.52 \%$ \\
\hline UNIVERSITY SYSTEM OF GEORGIA & 40 & $1.41 \%$ \\
\hline HEFEI UNIVERSITY OF TECHNOLOGY & 38 & $1.34 \%$ \\
\hline $\begin{array}{l}\text { PENNSYLVANIA COMMONWEALTH SYSTEM OF HIGHER } \\
\text { EDUCATION PCSHE }\end{array}$ & 38 & $1.34 \%$ \\
\hline UNIVERSITY OF ILLINOIS SYSTEM & 38 & $1.34 \%$ \\
\hline UNIVERSITY OF ILLINOIS URBANA CHAMPAIGN & 38 & $1.34 \%$ \\
\hline GEORGIA INSTITUTE OF TECHNOLOGY & 34 & $1.20 \%$ \\
\hline INDIAN INSTITUTE OF TECHNOLOGY SYSTEM IIT SYSTEM & 34 & $1.20 \%$ \\
\hline NANKAI UNIVERSITY & 34 & $1.20 \%$ \\
\hline SHANGHAI JIAO TONG UNIVERSITY & 34 & $1.20 \%$ \\
\hline TSINGHUA UNIVERSITY & 34 & $1.20 \%$ \\
\hline PENN STATE UNIVERSITY & 33 & $1.16 \%$ \\
\hline CHINESE ACADEMY OF SCIENCES & 32 & $1.13 \%$ \\
\hline HONG KONG POLYTECHNIC UNIVERSITY & 30 & $1.06 \%$ \\
\hline NANYANG TECHNOLOGICAL UNIVERSITY & 30 & $1.06 \%$ \\
\hline
\end{tabular}

Table 5 lists the top research areas in remanufacturing, as defined by Web of Science. As remanufacturing is a technical subject, it is no surprise that the area with the highest number of journals is industrial and manufacturing engineering research, for which the engineering manufacturing area is included in the majority of publications. The second highest record belongs to management, as remanufacturing has a strong connection with the organization and coordination of the activities. Environmental science has the next highest record, as remanufacturing is a type of manufacturing that is particularly environmentally conscious. 
Table 5: Top Research Areas in Remanufacturing

\begin{tabular}{|c|c|c|}
\hline Categories & Record Count & $\%$ of Total Publications \\
\hline ENGINEERING MANUFACTURING & 849 & $29.92 \%$ \\
\hline OPERATIONS RESEARCH MANAGEMENT SCIENCE & 784 & $27.63 \%$ \\
\hline ENGINEERING INDUSTRIAL & 768 & $27.06 \%$ \\
\hline ENGINEERING ENVIRONMENTAL & 371 & $13.07 \%$ \\
\hline ENVIRONMENTAL SCIENCES & 360 & $12.69 \%$ \\
\hline MANAGEMENT & 304 & $10.71 \%$ \\
\hline GREEN SUSTAINABLE SCIENCE TECHNOLOGY & 280 & $9.87 \%$ \\
\hline ENGINEERING MECHANICAL & 272 & $9.58 \%$ \\
\hline ENGINEERING ELECTRICAL-ELECTRONIC & 240 & $8.46 \%$ \\
\hline AUTOMATION CONTROL SYSTEMS & 224 & $7.89 \%$ \\
\hline MATERIALS SCIENCE MULTIDISCIPLINARY & 218 & $7.68 \%$ \\
\hline $\begin{array}{l}\text { COMPUTER SCIENCE INTERDISCIPLINARY } \\
\text { APPLICATIONS }\end{array}$ & 184 & $6.48 \%$ \\
\hline COMPUTER SCIENCE ARTIFICIAL INTELLIGENCE & 136 & $4.79 \%$ \\
\hline ENGINEERING MULTIDISCIPLINARY & 135 & $4.76 \%$ \\
\hline COMPUTER SCIENCE-INFORMATION SYSTEMS & 112 & $3.95 \%$ \\
\hline BUSINESS & 109 & $3.84 \%$ \\
\hline COMPUTER SCIENCE THEORY METHODS & 82 & $2.89 \%$ \\
\hline METALLURGY METALLURGICAL ENGINEERING & 68 & $2.40 \%$ \\
\hline ECONOMICS & 59 & $2.08 \%$ \\
\hline MATHEMATICS INTERDISCIPLINARY APPLICATIONS & 56 & $1.97 \%$ \\
\hline ENGINEERING MANUFACTURING & 849 & $29.92 \%$ \\
\hline OPERATIONS RESEARCH MANAGEMENT SCIENCE & 784 & $27.63 \%$ \\
\hline ENGINEERING INDUSTRIAL & 768 & $27.06 \%$ \\
\hline ENGINEERING ENVIRONMENTAL & 371 & $13.07 \%$ \\
\hline ENVIRONMENTAL SCIENCES & 360 & $12.69 \%$ \\
\hline
\end{tabular}




\subsection{Scientific Mapping of the Remanufacturing Field}

Following the review of the retrieved data by certain areas, such as key individuals, organizations and categories, the next stage is to conduct a more thorough examination of the remanufacturing field by using the proposed tech-mining method, as described in the methodology section. Accordingly, four main research clusters are identified, as proposed in the model for study shown in Figure 4.

These main remanufacturing research areas based on four identified clusters are: (1) Production planning and control of remanufacturing (cluster 1), (2) Material and remanufacturing engineering (cluster 2), (3) Supply chain management of the remanufacturing process (cluster 3) and, (4) Remanufacturing applications and new trends (cluster 4).

As a result of co-occurrence measurements, there are various intersections between these clusters, where various sub-fields are merged with each other. The research areas where technology, business and engineering related domains intersect with each other are material engineering and material related business management topics (see the term 'material' at an intersecting point). Furthermore, the research areas where production planning and supply chain related topics merge with each other are policy-related studies (see the term 'policy' at an intersecting point). 


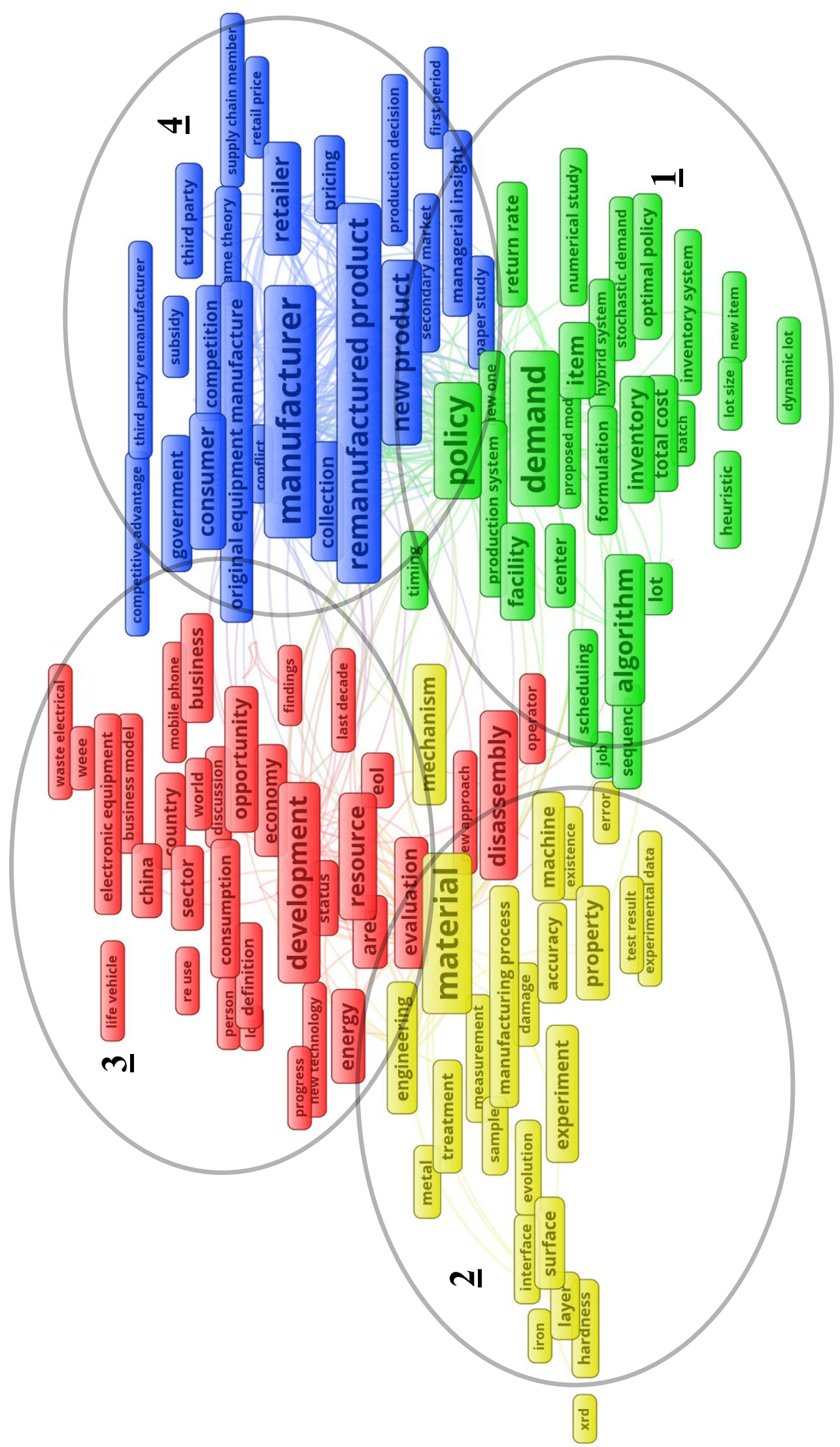

Figure 4: Remanufacturing Research Clusters and Intersections 
Using a quantitative technique, we categorize remanufacturing studies into four different clusters, as illustrated by Figure 4. The studies included in the literature review grouped the remanufacturing and related studies using classical review methods. An important example is Fleischmann et al. (1997), who examined the field of remanufacturing and the reverse logistics area. Their two categories (production planning and inventory control) are consistent with our cluster 1 and their third category (distribution planning) is consistent with our cluster 3 . Another important review study, Gungor and Gupta (1999), divided studies in remanufacturing into smaller groups; our cluster 1 and cluster 3 covers these groups. Similarly, the forecasting and reverse logistic group of Guide (2000) reflects our cluster 3, while their inventory management and production planning groups reflect our cluster 1. Thus, the groups of Guide (2000) are consistent with our two clusters. In another important review of studies, Ilgin and Gupta (2010) grouped the studies in the field of remanufacturing; all the groups they determined can be collected under our cluster 1 and 3. Meanwhile, Wang et al. (2017) grouped the research content of the reverse logistics field into operational and strategic. They also grouped the studies under strategic into four. One of these is supply chain, which corresponds to our cluster 3.

In addition to the groupings in the above-mentioned studies, we identify two more clusters (cluster 2 and 4) using a quantitative technique. Material and manufacturing engineering are merged in cluster 2. Materials science and engineering is the design and discovery of new materials. Remanufacturing engineering is the senior stage of maintenance engineering and surface engineering, and the important part of advanced manufacturing, and the industrialization for the waste products with repair and reformation (Bin-shi, 2010). For remanufacturing, it is not only planning and supply chain management but also material science and manufacturing engineering that are important. For this reason, there are numerous studies on this subject in the literature. The top research areas previously listed in Table 5 indicates this field; furthermore, the top author in the remanufacturing field (as shown in Table 2) is working in this area especially. For these reasons, studies in this area clearly form cluster 2.

In the literature, in addition to papers that develop a mathematical model and do applications based on this, some papers explain and discuss the importance of this field, present the applications in industry and conduct case studies. In this context, cluster 4 is formed by papers providing general knowledge about the remanufacturing business, the remanufacturing industry, its benefits, its economic impact, and the latest trends in the remanufacturing business.

The reason why our clusters 2 and 4 are not used in other review studies is due to the grouping method used by the reviewers: the authors grouped the papers in the literature according to activities in reverse logistics or remanufacturing. Because material and remanufacturing engineering and new trends are not an activity, they are not included in their groupings. As there are numerous studies in these fields, they form separate clusters in our study.

Overall, central studies in the remanufacturing field are related to the life cycle of materials, types of remanufacturers' involvement, different materials and components' related remanufacturing processes and remanufacturing policy-related studies based on the level of term frequency. In general, the mapping identified many clusters that are related to the waste management, OEMs vs. remanufacturing-based competitions, remanufacturing process of certain technologies and items such as engines and electronics, surface engineering and 
remanufacturing process optimization. All these sub-fields are described in the following sections with regards to their research focus, emerging developments (i.e. use of nano-surface engineering) and the interrelationship of different clusters with each other. The following sections examine these clusters in more depth, magnifying each clustering result.

\section{Research Cluster 1: Production Planning and Control of Remanufacturing}

In the production planning and control cluster, there are studies including words of production planning, hybrid system, lead time, demand, inventory management, stock, mathematical model, and optimal solution (see Figure 5). Here, the papers' main aim is to decide on the correct production order quantity and timing under the uncertainty of demand and return rate. The basic problem for production planning and control remanufacturing is to determine how much and when to disassemble and remanufacture, how much to produce and/or order for new materials, and how to coordinate disassembly and reassembly. The system should be able to coordinate a mix of remanufacturing and new production (Guide et al., 1999).

The categorization of Guide (1999), Junior and Filho (2012), and Lee et al. (2017) under the production planning of remanufacturing generally corresponds to the sub clusters we define under cluster 1 . The difference is that they have separate clusters for production planning and control, inventory control and management, and production planning and scheduling, whereas we group these studies under sub cluster 2 . The words representing these areas clearly appear in our numerical grouping (See Figure 5); while names given to groups in the studies of Guide (1999) and Junior and Filho (2012) coincide with the words that appear in our cluster 1.

As shown in sub-cluster 1, researchers have attempted to find optimum solutions by developing mathematical models for the systems, with defined new policies and assumptions. Production planning in a remanufacturing system environment is a more complex and uncertain process compared to the traditional manufacturing system. These complicated characteristics of remanufacturing include uncertainty in the timing and the quantity of returns, balancing returns with demands, disassembly, uncertainty in the materials recovered, reverse logistics, materials matching requirements, and routing uncertainty and processing time uncertainty (Guide, 2000). For this reason, researchers need to define new policies and assumptions to solve these problems. Guide (2000) listed major research issues in the literature belonging to each of these seven defined complicated characteristics. Forecasting is necessary both for product returns and for product demand; developing a reliable forecasting method is critical for facilitating effective production planning and control (Matsumoto and Komatsu, 2015). The ultimate objective is to minimize the total cost of the hybrid manufacturing and remanufacturing system; however, as Junior and Filho (2012) observed, there are very few forecasting related studies, which is why these terms do not appear in the clustering visual.

The inventory management of recoverable products and components in remanufacturing has attracted most of the researchers'. As shown in sub-cluster 2 in Figure 5, many researchers study the inventory system problem on hybrid systems with manufacturing and remanufacturing options. The objective is to establish when and how much to produce under the uncertainty of demand and return rate to minimize the total setup and holding cost. The 
main production strategy options for the hybrid manufacturing and remanufacturing systems are push and pull controlled hybrid systems. Other systems defined in the literature are an extension of these.

As illustrated by sub-cluster 3 in Figure 5, there are articles that include numerical studies with different return rates and qualities. In a remanufacturing system, the uncertain quality and rate of the product returns make the production system more complex. Researchers study different scenarios generated, assigning different values for different return rates and qualities.

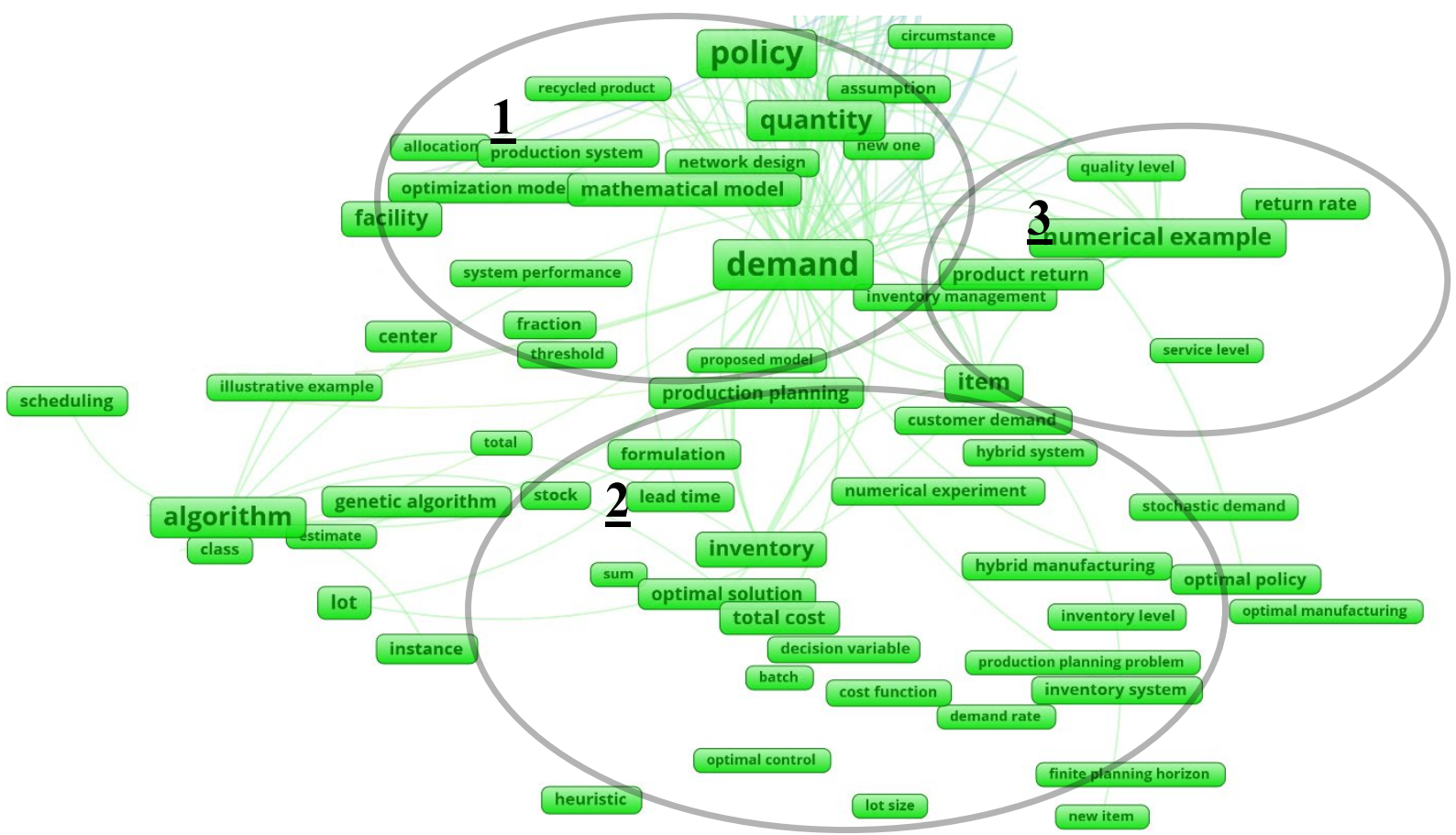

Figure 5: Production Planning and Control of Remanufacturing

\section{Research Cluster 2: Material and remanufacturing Engineering}

In the material and remanufacturing engineering cluster, there are studies including words of material engineering, such as force, steel, coating, temperature, test, failure and metal, as shown in Figure 6. Returned items must first be disassembled to value and use them. Eventually, certain material engineering related processes are followed so returned items can be used. Here, some of the papers study the techniques for processing the parts of disassembled returned products.

A complete remanufacturing system is formed from technical standards, processing techniques, and fabricating machinery to reverse logistics and delivery (Singh and Jain, 2014). Material and manufacturing engineering are merged in this cluster, as repairs on the surfaces of returned items are one of the crucial parts of the remanufacturing process. By using surface engineering techniques, waste parts in products can be repaired. The development of high and new technology has an important effect on promoting the remanufacturing engineering (Xu et al., 
2005). Lee at al. (2017) discussed papers under the sub cluster of remanufacturing technologies, grouping papers under design for disassembly, cleaning and repairing.

As shown in sub-cluster 1, micro to nano level applications focus on new techniques and materials. The studies in this field have demonstrated how micro- and nano-surface engineering possesses distinct advantages over the traditional techniques. Such applications can be listed as nano-materials, brush electroplating, nano-materials thermal spraying and nano-materials selfrepairing antifriction additive technology. These studies, especially nano level studies, can increase the capabilities in the remanufacturing process, applying such applications to some new, previously unadapted, items .

There are studies especially on surface engineering in the fields of green manufacturing. The application of surface engineering ranges from resisting wear and corrosion to preventing fatigue and creep. Surface engineering has seen a rapid development in the aviation, aerospace, new energy, new material, environmental protection and resources circulation industries (Xu et al., 2011). For example, by using surface engineering techniques, approximately $62 \%$ of waste parts in old engines can be repaired, and the quality of remanufactured engines become superior to the original products. The applications of advanced surface engineering techniques in engine remanufacturing have enhanced the availability of waste products, reduced the remanufacturing costs, and made valuable contributions to materials, energy-saving and environment protection (Xing et al., 2004)

Laser cladding and surface manufacturing are the key approaches, whereby materials such as iron and steel are remanufactured to fix coating and surface wear in different products such as crankshaft and rail surface (Li et al., 2018; Liu et al., 2018). Researchers have focused on such techniques, as the remanufacturing process requires materials and products to be returned to a like-new condition, and these researchers are attempting to improve the surface manufacturing process with regards to the application of different materials or nanoscale applications. Some researchers have also focused on the successful application of stress tests on the materials following the application of laser cladding approaches (Yan et al., 2018).

Reverse engineering and the treatment of the end of life construction machinery and tools is another area where many researchers have focused on remanufacturing in this field (see sub-cluster 2). This research area is a significant one due to the expense of such items and the number of materials being used in these products. Some of these construction machinery specific studies focus on the closed-loop supply chain networks to manage the flows of used items (Yi et al., 2016), the evaluation of life cycle for early detection (Wu et al., 2015) and the failure analysis and remanufacturing of some parts of the construction machinery (Ma et al., 2013).

The $3^{\text {rd }}$ sub-cluster illustrates studies in which numerous researchers have tested and measured damage, failures and defects on many items significant to the remanufacturing process. Many of these studies also focus on the accuracy of such tests, in order to examine the quality of the products after the application of the remanufacturing process. 


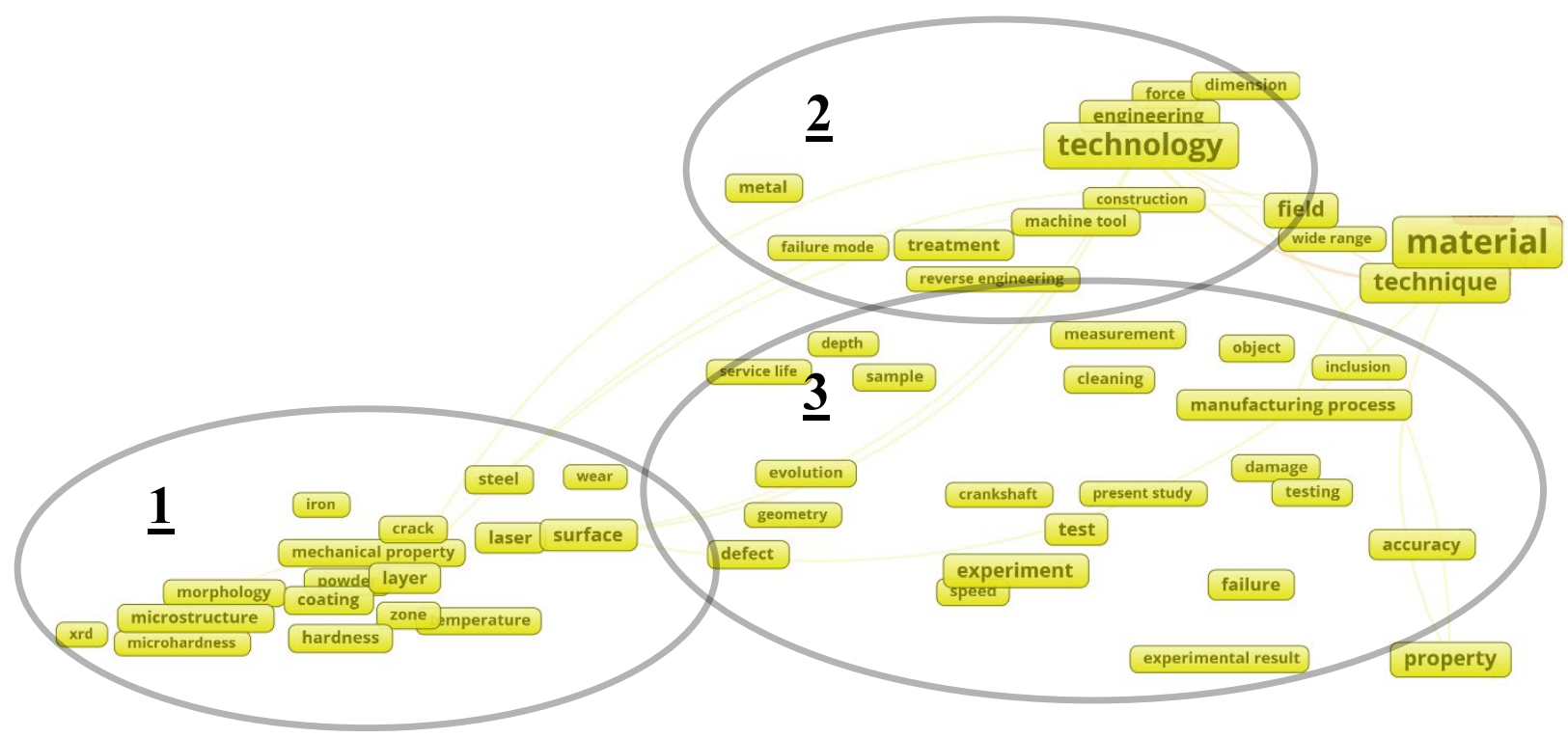

Figure 6: Material and remanufacturing engineering

\section{Research Cluster 3: Supply Chain Management of Remanufacturing Process}

Prahinski and Kocabasoglu (2006) defined reverse supply chain management as the effective and efficient management of the series of activities required to retrieve a product from a customer and either dispose of it or recover its value. The management of the reverse flows is an extension of the traditional supply chains, with used product or material either returning to reprocessing organizations or being discarded. The importance of studying reverse supply chains has increased in recent years.

The categorization of Prahinski and Kocabasoglu (2006) and Mutha (2009) under supply chain management and reverse logistics is consistent with the sub clusters we define under cluster 3 . The words representing these areas clearly appear in our numerical grouping (See figure 7). Names given to groups by Prahinski and Kocabasoglu (2006) and Mutha (2009) coincide with the words that appear in our cluster 3. Lee et al. (2017) also listed studies under a sub cluster of acquisition and the reverse logistics issue, which corresponds to our cluster 3.

In the supply chain management cluster, as illustrated in Figure 7, studies include words of competition, sales, pricing, profitability, used product collection, marketing and cannibalization. Here, the papers' principal aim is to decide on correct prices for the remanufactured products in order to maximize the profit. The pricing decision appears to be one of the most popular ones in the management side of this process; studies focus on the cost of remanufacturing under uncertainties to set the optimal price for the optimal profit.

As shown in sub-cluster 1, several remanufacturing studies have examined closed-loop supply chain models, focusing on the engagement of manufacturers, distributors, third parties and collectors (Gan et al., 2017; Huang and Wang, 2017). Some researchers have focused on pricing decision models for closed-loop supply chains, as one of the main concerns in this field is the cannibalization of the new product's sales (Xu et al., 2012). Accordingly, many 
researchers have focused on different types of channel and price-related strategies, in order to identify an optimal solution.

Another significant remanufacturing research area is illustrated in sub-cluster 2. This area mostly concerns the battle between OEMs and third-party manufacturer (TRPs). The cannibalization problem is also discussed here due to TRPs' entrance to the market. As shown in sub-cluster 2, there is an overall 'conflict' between OEMs, TRPs and their target consumer base. Accordingly, many scholars have attempted to model the environment to identify a suitable solution whereby these two types of organizations target a different customer base or else mutually support each other (Wu and Zhou, 2016). Some studies have focused on managing the remanufacturing process for TRPs independent of the involvement of OEMs and also on minimizing the complexity (Steinhilper et al., 2016).

Sub-cluster 3 represents research problems regarding remanufactured products, related to the production order quantity and timing under the uncertainty of market demand and return rate. Numerous studies have focused on the optimal conditions necessary to manage the market demand uncertainty in the secondary market, focusing on network configurations (Francas and Minner, 2009) and production-inventory systems (Gayon et al., 2017).

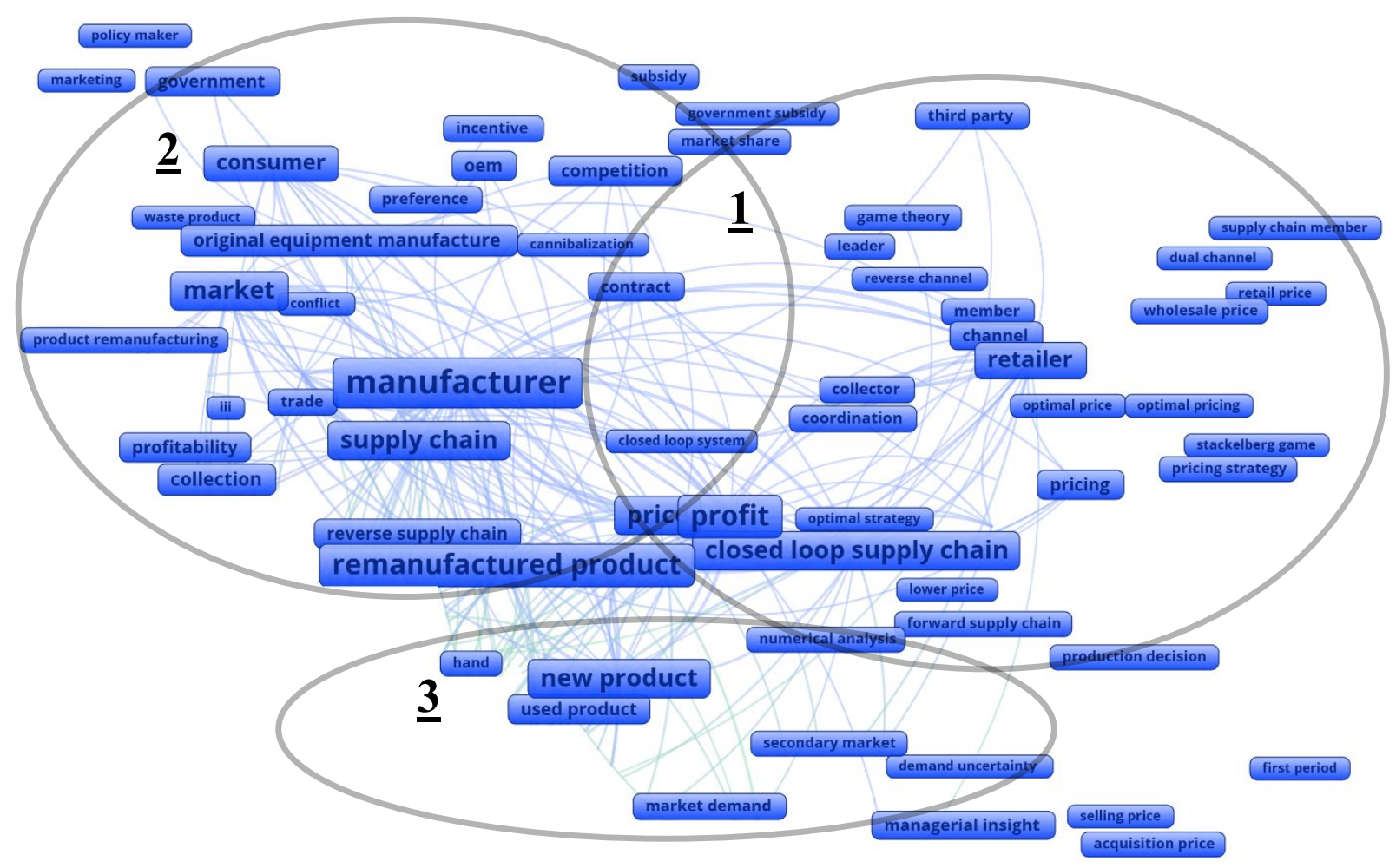

Figure 7: Supply chain management in remanufacturing

\section{Research Cluster 4: Remanufacturing Applications and New Trends}

In the remanufacturing business cluster, there are studies related to words of electronic equipment, WEEE, sector, China, economy, automotive part and legislation (see Figure 8). Here, the papers mainly aim to provide general knowledge regarding the remanufacturing 
business. The benefits of remanufacturing and the latest trends in the remanufacturing business are also presented.

Remanufacturing is practiced in many industries including those that sell photocopiers, computers, telecommunication equipment, automotive parts, office furniture and tires. The cost of remanufacturing is less compared to manufacturing a new product, as many parts and components are reused (Ferguson, 2009). This has already been applied to various products such as automobile parts, machinery, ink cartridges, medical devices and furniture (Lee et al., 2017). Lund and Hauser (2010) identified 113 product areas in which remanufacturing occur. In the US, the major product areas are motor vehicle parts, electrical motors and generators, pumps, transformers, laser toner cartridges, industrial machinery, tires, industrial valves and office furniture.

As shown in sub-cluster 1 in Figure 8, remanufacturing processes are very important for the circular economy and, relatedly, WEEE (Waste Electrical and Electronic Equipment) such as computers, TV-sets, fridges and cell phones, and e-waste with the use of cloud systems, appear to be a very popular cluster of studies in this field. Many studies have attempted to find a better method of remanufacturing for electronic equipment waste and especially parts such as toner cartridges. WEEE is one of the fastest growing wastes in the EU, with approximately 9 million tons in 2005, and this is expected to grow to more than 12 million tons by 2020. Therefore, WEEE needs to be remanufactured due to its hazardous content, as it may lead to environmental problems. Numerous studies have examined the process of remanufacturing for WEEE in terms of its cleaning, disassembling, reprocessing and reassembling. To improve the environmental management of WEEE, two different directives (WEEE Directive and RoHS Directive) are working together (Kumar and Putnam, 2008). China and Korea have followed the EU in promulgating regulations to manage electronic equipment waste, to ensure its electronic exports can compete globally and to improve electronics waste programmes. Statistics released by the China Electronics Import \& Export Corporation estimate that $70 \%$ of China's electronics exports will be impacted by WEEE and RoHS requirements (Kumar and Putnam, 2008). Apart from OECD's EPR programme, in the US many of the electronics companies (e.g. Xerox, Microsoft, Acer, Apple, Asus, Dell, HP, Canon, Kodak, Lenovo, LG, Toshiba, Samsung, Panasonic, Mitsubishi) have voluntary take-back programmes, although there is no law requiring this (electronicstakeback.com).

As depicted in sub-cluster 1 in Figure 8, many studies target the remanufacturing activities in China. Considering the considerable economic and environmental benefits of the remanufacturing process, this field has been long promoted by the Chinese government through laws and policies since 2005. Many studies have examined this field in the China region with a management perspective, focusing on the supply chain, financial benefits and implementation barriers, etc. Furthermore, the studies mostly focus on the automotive parts' and electronics products' remanufacturing process in China, and this may be a reflection of their focus on the remanufacturing industry, as China is the largest exporter in the electronics industry and the fourth biggest exporter of automotive parts. Lee at al. (2017) discussed remanufacturing activities under different countries such as the US, EU, China, Brazil, India, Japan, Singapore and Korea. 
The increasing amount of energy and material consumption is harming the environment. For this reason, sustainable manufacturing is more important than ever before. The end-of-life (EOL) strategies for products and product recovery options mentioned in Table 1 have been popular. Remanufacturing the used products instead of manufacturing new ones has been claimed to save energy and resources. As shown in sub-cluster 2 in Figure 8, there are studies that discuss how remanufacturing saves energy. Some studies compare remanufactured device and new product performance in the use phase from an energy standpoint; the life cycle assessments framework is utilized for this purpose. Lee at al. (2017) presented papers under their sub cluster of environmental and economic issues.

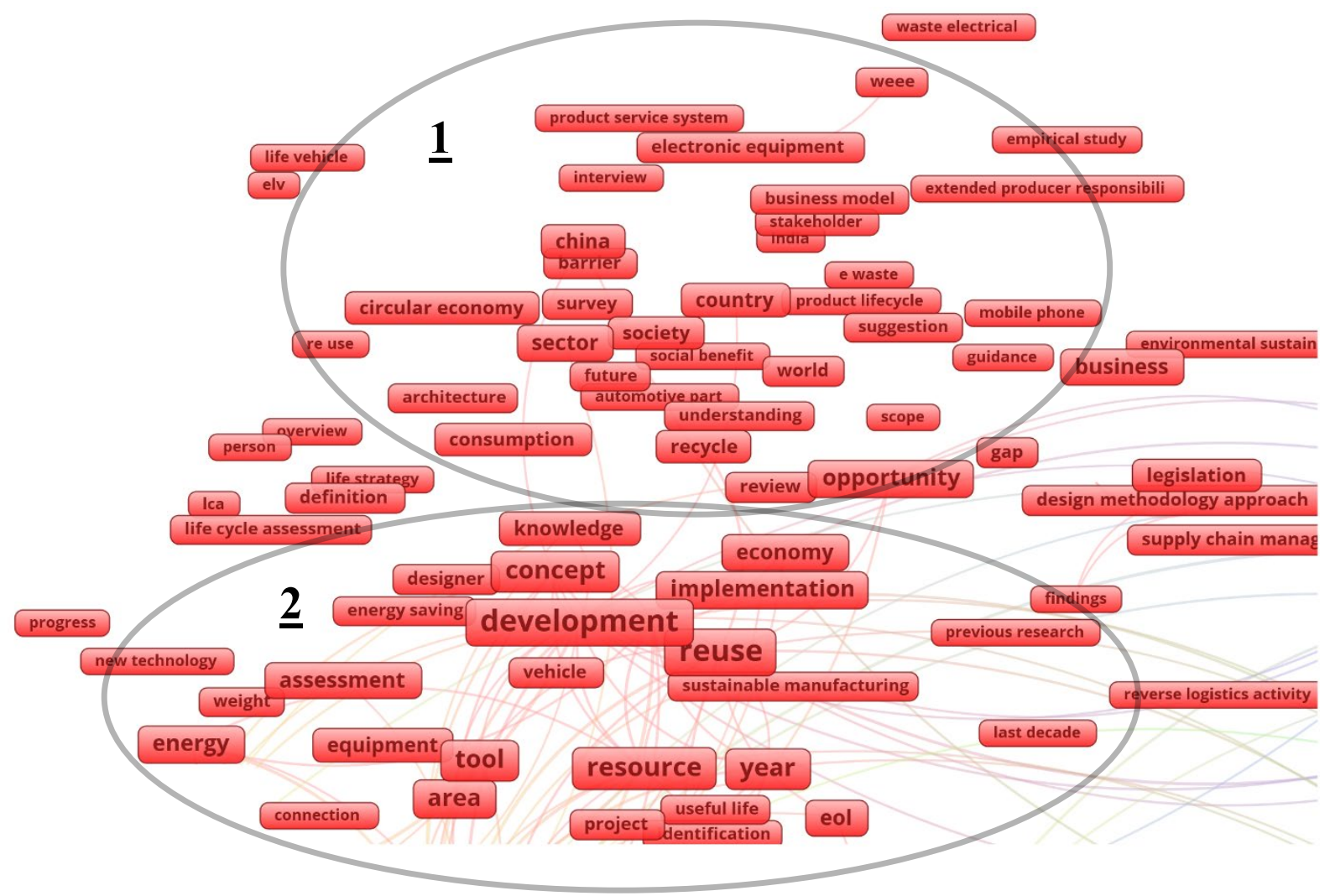

Figure 8: Remanufacturing Applications and New Trends

\section{Conclusions}

The aim of this study was to map scientific, organizational and national concentration zones by using an innovative method, as described. An examination of remanufacturing research involvement at an individual, organizational or national level shows that China and the US exert strong dominance at all levels. Nearly $60 \%$ of global research is the result of research activities of China and the US. The US usually has dominance in many areas as the top publishing nation, but China also has a dominance in this field due to their key role in global manufacturing and the types of materials and products that they manufacture.

A key group of researchers in this area are divided based on two generic remanufacturing functions: (1) Those researchers who are related to the management and business operations of the remanufacturing process and (2) Those researchers who are focusing on the product and 
process level remanufacturing problems. Some researchers, such as Gupta S. M. lead the management domain, while $\mathrm{Xu} \mathrm{B}$. S. leads the engineering domain. Likewise, the results indicate that many of the US-based scholars are focusing on managerial aspects and many in China are focusing on material and remanufacturing engineering-related research.

The examination of scientific fields reveals four distinct categories of remanufacturing research: (1) Production planning and control of remanufacturing, (2) Material and remanufacturing engineering, (3) Supply chain management of the remanufacturing process and, (4) Remanufacturing applications and new trends. Based on these four main clusters, Table 6 displays the scientometric output for the remanufacturing research categorizing sub-areas and their key research themes.

Table 6: Scientometric categorization of remanufacturing research

\begin{tabular}{|c|c|}
\hline Remanufacturing Research Areas & Key Research Themes \\
\hline $\begin{array}{l}\text { Production planning and control of } \\
\text { remanufacturing }\end{array}$ & $\begin{array}{ll}\text { - } & \text { Forecasting } \\
\text { - } & \text { Inventory management } \\
\text { - } & \text { Performance of hybrid manufacturing and remanufacturing } \\
\text { - } & \text { Lystems } \\
\text { - } & \text { Sched sizing } \\
\text { - } & \text { Ordering systems }\end{array}$ \\
\hline $\begin{array}{l}\text { Material and remanufacturing } \\
\text { engineering }\end{array}$ & $\begin{array}{ll}\text { - } & \text { Surface engineering } \\
\text { - } & \text { Micro- and nano-scale applications } \\
\text { - } & \text { Laser cladding } \\
\text { - } & \text { Teating applications } \\
\text { - } & \text { Reverse engineering } \\
\text { - } & \text { Closed-loop supply chain } \\
\text { - } & \text { Evaluation of life cycle for early detection } \\
\text { - } & \text { Identification of damages, failures and defects }\end{array}$ \\
\hline $\begin{array}{l}\text { Supply chain management of the } \\
\text { remanufacturing process }\end{array}$ & $\begin{array}{ll}\text { - } & \text { Closed-loop supply chains } \\
\text { - } & \text { Reverse supply chain } \\
\text { - } & \text { Pricing strategies } \\
\text { - } & \text { Uncertainty management } \\
\text { - } & \text { Engagement of supply chain actors } \\
\text { - } & \text { Integration of OEMs and TRPs } \\
\text { - } & \text { Modelling and optimization of supply chain } \\
\text { - } & \text { Production-inventory systems } \\
\text { - } & \text { Collection of used products }\end{array}$ \\
\hline
\end{tabular}




\begin{tabular}{|l|l|}
\hline \multirow{2}{*}{ Remanufacturing applications and } & - Energy saving \\
new trends & - Life cycle assessment \\
& - Product recovery options \\
& $\bullet$ Seconomies of remanufacturing \\
\hline
\end{tabular}

Compared to previous studies, this research adds considerable value in terms of generating the scientometric categorization of the remanufacturing field based on a quantitative and techmining based approach for which all management and engineering related research domains are used to illustrate the results. The findings of our study differ from the many other review studies mentioned in section 2 due to the identified engineering and application themes. Ilgin and Gupta (2010) categorised remanufacturing studies, as depicted in Figure 1, into six main areas. This categorization was achieved by a classical review of the literature. Our quantitative results categorise remanufacturing studies into four different clusters. Production planning and control of remanufacturing, and supply chain management of the remanufacturing process clusters include Ilgin and Gupta's (2010) categories. We also add two more clusters: material and remanufacturing engineering, and remanufacturing applications and new trends. Furthermore, we concur with the key author networks identified by Wang et al. (2017). Our findings also partially agree with the research gaps identified by Junior and Filho (2012). Accordingly, these authors identified limited studies in forecasting and aggregate planning and, since our visuals lacked these terms due to the low frequency of research in these areas, we can also confirm this. However, the applications of stochastic models are more frequently used in production planning and in the control of the remanufacturing research cluster, although Junior and Filho's study was conducted in 2012 and so there may have been research progress since then.

Cluster 1 and cluster 3 from our groupings are compatible with the groups used in many review studies. Although some studies (Guide, 1999; Gungor and Gupta, 1999; Guide, 2000; Ilgin and Gupta, 2010; Junior and Filho, 2012) have more groups in number with a smaller size, our cluster (cluster 1 or 3 ) covers two or more groups in these studies. In addition, at the end of the quantitative grouping technique, we identify two separate clusters (cluster 2 and 4) which are not found in any of the other well-known review studies mentioned.

In the literature, forecasting, inventory management and scheduling are the widely used research themes of cluster 1 , as shown in Table 6 . On the other hand, lot sizing and ordering systems are only used by Junior and Filho (2012) in the review articles mentioned above. No review study used the performance of hybrid manufacturing and remanufacturing systems as a research theme. Although majority of the research themes in cluster 1 were used as sub-cluster in some review articles, only some of the research themes such as economies of remanufacturing, collection of used products, reverse supply chain, surface engineering, collection of used products, engagement of supply chain actors were used with different titles in other clusters in review articles of Fleischmann et al. (1997), Guide (2000), Prahinski and Kocabasoglu (2006), Pokharel and Mutha (2009), Subramoniam et al. (2009), Lee et. al. (2017), and Wang et al. (2017). 
Another contribution of our study is related to the intersection of clusters. The adoption of this scientometric approach for all remanufacturing data enabled us to clearly demonstrate how business and engineering related topics merge together at different types of research concerns and applications. Finally, this study also illustrated the national and organizational remanufacturing competences.

The limitations of this study include the fact that it is mainly based on a publication database and could be further improved by the use of patent databases in another study, which would focus on the industrial applications of remanufacturing and innovations in this field. This study also could be further extended with interviews with identified key individuals. This would help the field to be examined further in-depth, and their opinions could also be obtained, thus offering further insight into this research area.

We believe this study can be highly beneficial to those who have been recently involved in a specific research area in remanufacturing research, in addition to those who wish to choose one in the future. Most importantly, this study can be highly beneficial for policymakers in establishing their national, regional or sectoral strategies accordingly. The outputs of the scientometric approach should prove to be of considerable assistance to the academy in categorizing remanufacturing research for bibliometric purposes.

\section{References}

Arora, S. K., Porter, A. L., Youtie, J., \& Shapira, P. (2013). Capturing new developments in an emerging technology: an updated search strategy for identifying nanotechnology research outputs. Scientometrics, 95(1), 351-370.

Atasu, A., Guide, V. D. R. Jr, \& Van Wassenhove, L. N. (2010). So what if remanufacturing cannibalizes my new product sales. California Management Review, 52(2), 56-76.

Bayındır, Z.P., Erkip, N., Güllü, R., 2003. A model to evaluate inventory costs in a remanufacturing environment. Int. J. Prod. Econ. 81-82, 597-607.

Behret, H., Korugan, A. (2009) Performance analysis of a hybrid system under quality impact of returns. Computers \& Industrial Engineering, 56, 507-520.

Bernard, S. (2011). Remanufacturing. Journal of Environmental Economics and Management, 62(3), 337-351.

Bin-shi, X. U. (2010). State of the art and future development in remanufacturing engineering [J]. Transactions of Materials and Heat Treatment, 1.

Bourgeois, H. (2004). Renault Trucks: Remanufacturing as a strategic activity. IMD - International Institute for Management Development. Lausanne, Switzerland.

Bras, B., \& McIntosh, M. W. (1999). Product, process, and organizational design for remanufacture-an overview of research. Robotics and Computer-Integrated Manufacturing, 15(3), 167-178.

Chen, C., Wang, Y., Ou, H., He, Y., \& Tang, X. (2014). A review on remanufacture of dies and moulds. Journal of Cleaner Production, 64, 13-23.

Corum, A. (2016). Remanufacturing, an added value product recovery strategy. Handbook of research on waste management techniques for sustainability, 347-367.

Corum, A., Vayvay, Ö., \& Bayraktar, E. (2014). The impact of remanufacturing on total inventory cost and order variance. Journal of cleaner production, 85, 442-452.

Ebersole, P. (1997). Making it (almost) new again. Operation Management (10th ed., pp. 139-140). New York: McGraw-Hill.

Ellen Macarthur Foundation, 2014. Towards the Circular Economy Vol. 3: Accelerating the Scale-up across Global Supply Chains. 
El Saadany, A. M., Jaber, M. Y., \& Bonney, M. (2013). How many times to remanufacture?. International Journal of Production Economics, 143(2), 598-604.

Esenduran, G., Kemahlioğlu-Ziya, E., \& Swaminathan, J. M. (2012). Product take-back legislation and its impact on recycling and remanufacturing industries. Sustainable Supply Chains (pp. 129-148). Springer New York.

Ferguson, M. (2009). Strategic issues in closed-loop supply chains with remanufacturing. Closed-Loop Supply Chains: New Developments to Improve the Sustainability of Bus. Practices (pp. 9-22).

Fleischmann, M., Bloemhof-Ruwaard, J. M., Dekker, R., Van der Laan, E., Van Nunen, J. A., \& Van Wassenhove, L. N. (1997). Quantitative models for reverse logistics: A review. European Journal of Operational Research, 103(1), 1-17.

Francas, D., \& Minner, S. (2009). Manufacturing network configuration in supply chains with product recovery. Omega, 37(4), 757-769.

Gan, S. S., Pujawan, I. N., \& Widodo, B. (2017). Pricing decision for the new and remanufactured product in a closed-loop supply chain with separate sales-channel. International Journal of Production Economics, 190, 120 132.

Gayon, J. P., Vercraene, S., \& Flapper, S. D. P. (2017). Optimal control of a production-inventory system with product returns and two disposal options. European Journal of Operational Research, 262(2), 499-508.

Guan, J., \& Zhao, Q. (2013). The impact of university-industry collaboration networks on innovation in nanobiopharmaceuticals. Technological Forecasting and Social Change, 80(7), 1271-1286.

Guide Jr, V. D. R., Jayaraman, V., \& Srivastava, R. (1999). Production planning and control for remanufacturing: a state-of-the-art survey. Robotics and Computer-Integrated Manufacturing, 15(3), 221-230.

Guide Jr., V.D.R., Teunter, R.H., Van Wassenhove, L.N. (2003) Matching demand and supply to maximize profits from remanufacturing. Manufacturing \& Service Operations Management, 5(4), 303-316.

Guide, V. D. R. Jr, Srivastava, R., \& Kraus, M. E. (1997). Product structure complexity and scheduling of operations in recoverable manufacturing. International Journal of Production Research, 35(11), 3179-3200.

Guide, V. D. R. Jr. (2000). Production planning and control for remanufacturing: Industry practice and research needs. Journal of Operations Management, 18(4), 467-483.

Guo, Y., Zhou, X., Porter, A.L., \& Robinson, D.K.R., (2015). Tech mining to generate indicators of future national technological competitiveness: Nano-Enhanced Drug Delivery (NEDD) in the US and China.Technological Forecasting \& Social Change.97, pp. 168-180.

Gungor, A., \& Gupta, S. M. (1999). Issues in environmentally conscious manufacturing and product recovery: A survey. Computers \& Industrial Engineering, 36(4), 811-853.

Hatcher, G. D., Ijomah, W. L., \& Windmill, J. F. C. (2011). Design for remanufacture: A literature review and future research needs. Journal of Cleaner Production, 19(17), 2004-2014.

Huang, Y., \& Wang, Z. (2017). Closed-loop supply chain models with product take-back and hybrid remanufacturing under technology licensing. Journal of cleaner production, 142, 3917-3927.

Ilgin, M. A., \& Gupta, S. M. (2010). Environmentally conscious manufacturing and product recovery (ECMPRO): A review of the state of the art. Journal of Environmental Management, 91(3), 563-591.

Johnson, M. R., \& Wang, M. H. (1995). Planning product disassembly for material recovery opportunities. International journal of production research, 33(11), 3119-3142.

Junior, M. L., \& Filho, M. G. (2012). Production planning and control for remanufacturing: literature review and analysis. Production Planning \& Control, 23(6), 419-435.

Kenne, J. P., Dejax, P., \& Gharbi, A. (2012). Production planning of a hybrid manufacturing/remanufacturing system under uncertainty within a closed-loop supply chain. International Journal of Production Economics, $135(1), 81-93$.

Kerr, W., \& Ryan, C. (2001). Eco-efficiency gains from remanufacturing: A case study of photocopier remanufacturing at Fuji Xerox Australia. Journal of Cleaner Production, 9(1), 75-81.

King, A. M., Burgess, S. C., Ijomah, W., \& McMahon, C. A. (2006). Reducing waste: Repair, recondition, remanufacture or recycle? Sustainable Development, 14(4), 257-267. 
Kumar, R., \& Ramachandran, P. (2016). Revenue management in remanufacturing: perspectives, review of current literature and research directions. International Journal of Production Research, 54(7), 2185-2201.

Kumar, S., \& Putnam, V. (2008). Cradle to cradle: Reverse logistics strategies and opportunities across three industry sectors. International Journal of Production Economics, 115(2), 305-315.

Laan, E., Salomon, M. (1997) Production planning and inventory control with remanufacturing and disposal. European Journal of Operational Research, 102, 264-278.

Laan, E., Salomon, M., Dekker, R., Wassenhove, L.N. (1999) Inventory control in Hybrid Systems with Remanufacturing. Management science, 45(5), 733-747.

Lee, H.L., Padmanabhan, V., Whang, S., 1997. Information distortion in a supply chain: the bullwhip effect. Management Science 43 (4), 546-558.

Lee, C. M., Woo, W. S., \& Roh, Y. H. (2017). Remanufacturing: Trends and issues. International Journal of Precision Engineering and Manufacturing-Green Technology, 4(1), 113-125.

Leydesdorff, L., Carley, S., \& Rafols, I. (2013). Global maps of science based on the new Web-of-Science categories. Scientometrics, 94(2), 589-593.

Leydesdorff, L., \& Rafols, I. (2009). A global map of science based on the ISI subject categories. Journal of the Association for Information Science and Technology, 60(2), 348-362.

Leydesdorff, L., \& Rafols, I. (2011). Indicators of the interdisciplinarity of journals: Diversity, centrality, and citations. Journal of Informetrics, 5(1), 87-100.

Leydesdorff, L., Rafols, I., \& Chen, C. (2013). Interactive overlays of journals and the measurement of interdisciplinarity on the basis of aggregated journal-journal citations. Journal of the Association for Information Science and Technology, 64(12), 2573-2586.

Leydesdorff, L., \& Zhou, P. (2007). Nanotechnology as a field of science: Its delineation in terms of journals and patents. Scientometrics, 70(3), 693-713.

Li, Y., Dong, S., Yan, S., Liu, X., He, P., \& Xu, B. (2018). Surface remanufacturing of ductile cast iron by laser cladding Ni-Cu alloy coatings. Surface and Coatings Technology, 347, 20-28.

Li, X., Zhou, Y., Xue, L., \& Huang, L., (2015). Integrating bibliometrics and roadmapping methods: A case of dye-sensitized solar cell technology-based industry in China. Technological Forecasting \& Social Change. 97 , pp. 205-222.

Liu, J., Ma, C., Yu, L., Wang, Y., \& Jiao, Z. (2018). Remanufacturing of nodular cast iron crankshaft with plasma cladding. Advances in Mechanical Engineering, 10(6), 1687814018779852

Lund, R. (1983). Remanufacturing: United States Experience and Implications for Developing Nations. Washington, DC: The World Bank.

Lund, R. T., \& Hauser, W. M. (2010). Remanufacturing-an American perspective. ICRM 2010- Green Manufacturing, Ningbo, China.

Ma, N., Wu, H. T., Ye, F. X., \& Zhang, G. S. (2013). Failure Analysis and Remanufacturing of Construction Machinery Shafts by HVOF Technique. In Applied Mechanics and Materials (Vol. 423, pp. 771-774). Trans Tech Publications.

Matsumoto, M., \& Komatsu, S. (2015). Demand forecasting for production planning in remanufacturing. The International Journal of Advanced Manufacturing Technology, 79(1-4), 161-175.

Matsumoto, M., \& Umeda, Y. (2011). An analysis of remanufacturing practices in Japan. Journal of Remanufacturing, 1(1), 2.

Mitra, S. (2007) Revenue management for remanufactured products. Omega 35, 553 - 562.

Newman, N.C., Porter, A.L., Newman, N., Courseault Trumbach, C., \& Bolan, S.D., (2014). Comparing methods to extract technical content for technological intelligence. J. Eng. Technol. Manage. 32, pp. 97-109.

Ogawa, T. ve Kajikawa, Y., (2014). Assessing the industrial opportunity of academic research with patent relatedness: A case study on polymer electrolyte fuel cells. Technological Forecasting \& Social Change.90, pp. $469-475$.

Ozcan, S., \& Islam, N. (2014). Collaborative networks and technology clusters-The case of nanowire. Technological Forecasting and Social Change, 82, 115-131. 
OECD. (2001). Extended Producer Responsibility: A Guidance Manual for Governments. Paris: OECD Publishing.

OECD. (2014). The State of Play on Extended Producer Responsibility (EPR): Opportunities and Challenges. Issues paper of Global Forum on Environment: Promoting Sustainable Materials Management through Extended Producer Responsibility (EPR). Tokyo, Japan.

Oh, Y. H., \& Hwang, H. (2006). Deterministic inventory model for recycling system. Journal of Intelligent Manufacturing, 17(4), 423-428.

Östlin, J., Sundin, E., \& Björkman, M. (2008). Importance of closed-loop supply chain relationships for product remanufacturing. International Journal of Production Economics, 115(2), 336-348. doi:10.1016/j. ijpe. 2008.02 .020

Ozcan, S., \& Islam, N. (2017). Patent information retrieval: approaching a method and analyzing nanotechnology patent collaborations. Scientometrics, 111(2), 941-970.

Pati, K.R., Vrat, P., Kumar, P. (2010) Quantifying bullwhip effect in a closed loop supply chain. Opsearch, 47(4), 231-253.

Pellerin, R., Sadr, J., Gharbi, A., Malhamé, R. (2009) A production rate control policy for stochastic repair and remanufacturing systems. Int. J. Production Economics, 121, 39-48.

Pokharel, S., \& Mutha, A. (2009). Perspectives in reverse logistics: a review. Resources, Conservation and Recycling, 53(4), 175-182.

Porter, A. L., \& Cunningham, S. W. (2004). Tech mining: exploiting new technologies for competitive advantage (Vol. 29). John Wiley \& Sons.

Porter, A. L., \& Youtie, J. (2009). How interdisciplinary is nanotechnology?. Journal of nanoparticle research, 11(5), 1023-1041.

Pourghadim, V. A., Noordin, M. Y., \& Wong, K. Y. (2014). A Review of Inventory Management for Remanufacturing Environment. In Advanced Materials Research (Vol. 845, pp. 618-622). Trans Tech Publications.

Prahinski, C., \& Kocabasoglu, C. (2006). Empirical research opportunities in reverse supply chains. Omega, 34(6), 519-532.

Priyono, A., Ijomah, W., \& Bititci, U. (2016). Disassembly for remanufacturing: A systematic literature review, new model development and future research needs. Journal of Industrial Engineering and Management, 9(4), 899-932.

Rafols, I., M. Meyer (2007), How cross-disciplinary is bionanotechnology? Explorations in the specialty of molecular motors. Scientometrics, 70 (3), 633-650.

Saavedra, Y. M., Barquet, A. P., Rozenfeld, H., Forcellini, F. A., \& Ometto, A. R. (2013). Remanufacturing in Brazil: Case studies on the automotive sector. Journal of Cleaner Production, 53, 267-276.

Seitz, M., \& Peattie, K. (2004). Meeting the closed-loop challenge. California Management Review, 46(2), 74 89.

Shapira P., Youtie J., Kay L., (2011). National innovation systems and the globalization of nanotechnology innovation. The Journal of Technology Transfer. 36, 587-604.

Singh, H., \& Jain, P. K. (2014, December). Electrochemical honing of mating clad surfaces-a concept towards remanufacturing engineering. In Proceedings of International Conference on Production and Mechanical Engineering (ICPME'2014). International Academy of Engineers (IA-E), Bangkok, Thailand Dec (pp. 30-31).

Singh, J., \& Ordoñez, I. (2016). Resource recovery from post-consumer waste: important lessons for the upcoming circular economy. Journal of Cleaner Production, 134, 342-353.

Smith, S. (2005). Analytical framework for evaluating the costs and benefits of extended producer responsibility programmes. Paris: OECD Publishing.

Steinhilper, R., Kleylein-Feuerstein, J., \& Kussmann, C. (2016, September). Remanufacturing and upcycling of an industrial robot handheld terminal independently from the original equipment manufacturer. In Electronics Goes Green 2016+(EGG), 2016 (pp. 1-8). IEEE 
Subramoniam, R., Huisingh, D., \& Chinnam, R. B. (2009). Remanufacturing for the automotive aftermarketstrategic factors: literature review and future research needs. Journal of Cleaner Production, 17(13), 1163-1174.

Subramoniam, R., Huisingh, D., Chinnam, R. B., \& Subramoniam, S. (2013). Remanufacturing DecisionMaking Framework (RDMF): Research validation using the analytical hierarchical process. Journal of Cleaner Production, 40, 212-220.

Tang, O., \& Naim, M. M. (2004). The impact of information transparency on the dynamic behaviour of a hybrid manufacturing/remanufacturing system. International Journal of Production Research, 42(19), 4135-4152.

Teunter, R.H. (2001) A reverse logistics valuation method for inventory control. Int. J. Prod. Res., 39, 20232035 .

Teunter, R.H., Laan, E., Inderfurth, K. (2000) How to set the holding cost rates in average cost inventory models with reverse logistics. Omega, 28, 409-515.

Thierry, M., Salomon, M., Van Nunen, J., \& Van Wassenhove, L. (1995). Strategic issues in product recovery management. California Management Review, 37(2), 114-135.Wu, C.H., 2012. Product design and pricing strategies with remanufacturing. Eur. J. Oper. Res. 222 (2), 204-215

Wang, J. J., Chen, H., Rogers, D. S., Ellram, L. M., \& Grawe, S. J. (2017). A bibliometric analysis of reverse logistics research (1992-2015) and opportunities for future research. International Journal of Physical Distribution \& Logistics Management, 47(8), 666-687.

Wu, X., \& Zhou, Y. (2016). Does the Entry of Third-Party Remanufacturers Always Hurt Original Equipment Manufacturers? Decision Sciences, 47(4), 762-780.

Wu, Y., Li, W., \& Yang, P. (2015). A study of fatigue remaining useful life assessment for construction machinery part in remanufacturing. Procedia Corp, 29, 758-763.

Xing, Z., Jiang, A. L., Xie, J. J., \& Feng, Y. C. (2004). Benefit analysis and surface engineering application of automobile engine remanufacturing [J]. China Surface Engineering, 4.

Xu, B. S., Liu, S. C., \& Wang, H. D. (2005). Developing remanufacturing engineering, constructing cycle economy and building saving-oriented society. Journal of Central South University of Technology, 12(2), 1-6.

Xu, X., Li, Y., \& Cai, X. (2012). Optimal policies in hybrid manufacturing/remanufacturing systems with random price-sensitive product returns. International Journal of Production Research, 50(23), 6978-6998.

Xu, B. S., Tan, J., \& Chen, J. M. (2011). Science and technology development of surface engineering. China Surface Engineering, 2, 1-12.

Yan, X. L., Dong, S. Y., Xu, B. S., \& Cao, Y. (2018). Progress and Challenges of Ultrasonic Testing for Stress in Remanufacturing Laser Cladding Coating. Materials, 11(2), 293.

Yi, P., Huang, M., Guo, L., \& Shi, T. (2016). A retailer oriented closed-loop supply chain network design for end of life construction machinery remanufacturing. Journal of Cleaner Production, 124, 191-203.

Zanoni, S., Ferretti, I., Tang, O. (2006) Cost performance and bullwhip effect in a hybrid manufacturing and remanufacturing system with different control policies. International Journal of Production Research, 44(18-19), $3847-3862$.

Zhang, D. Q., Tan, S. K., \& Gersberg, R. M. (2010). Municipal solid waste management in China: status, problems, and challenges. Journal of Environmental Management, 91(8), 1623-1633.

Zhang, Y., Porter, A.L., Hu, Z., Guo, Y., \& Newman, N.C., (2014). “Term clumping” for technical intelligence: A case study on dye-sensitized solar cells. Technological Forecasting \& Social Change. 85, pp. 26-39.

Zhou, L., Disney, S.M. (2006) Bullwhip and inventory variance in a closed loop supply chain. OR Spectrum, 28 , 127-149. 


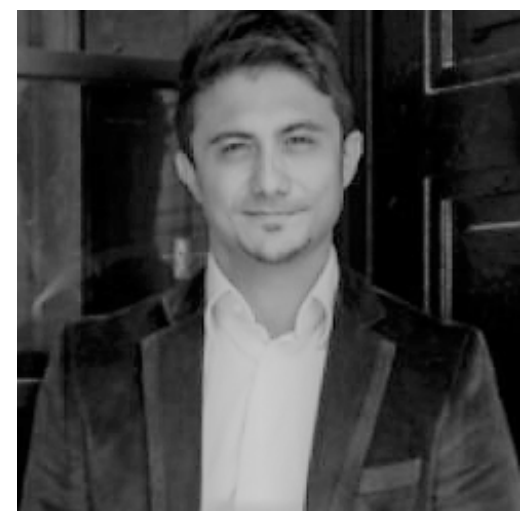

Sercan Ozcan is a senior lecturer in the Strategy, Enterprise and Innovation Subject Group at Portsmouth Business School. He holds a $\mathrm{PhD}$ in Innovation Management from Aberystwyth University, UK. Dr Sercan Ozcan has published in the top journals of Innovation Management and Engineering Management fields such as IEEE Transactions on Engineering Management, Technological Forecasting and Social Change, and R\&D Management. He has received various awards such as Best Paper by Early Career Researcher from Portsmouth Business School 2018, PICMET Brad Hosler Award for Outstanding Student Paper 2015 and ABTA

Doctoral Researcher Award 2014. He worked as a consultant with some private and governmental organisations in various innovation management projects and also worked with business incubation centres, mentorship programs and funding agencies to help with the process of establishing innovative start-ups.

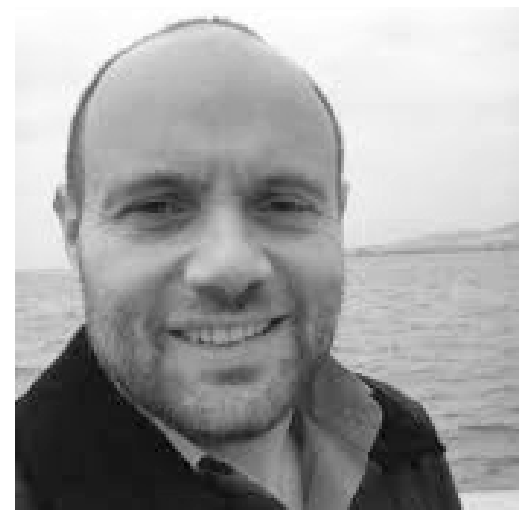

Adnan Corum is an Assistant Professor in the Department of Industrial Engineering, Bahcesehir University in Istanbul, Turkey. $\mathrm{He}$ is delivering courses on operations management, production planning and control, ERP systems, and engineering economy in both undergraduate and graduate levels. He has publications on planning of environmentally conscious manufacturing systems and financial decision making. 